\title{
Environmental impact of pharmaceuticals from Portuguese wastewaters: geographical and seasonal occurrence, removal and risk assessment
}

\author{
André M.P.T. Pereira ${ }^{\text {a }}$, Liliana J.G. Silva ${ }^{\mathrm{a},{ }^{*}, \text { Leonor M. Meisel }^{\mathrm{b}, \mathrm{c}} \text {, Celeste M. Lino }}{ }^{\mathrm{a}}$,
} Angelina Pena ${ }^{\mathrm{a}}$

\begin{abstract}
${ }^{a}$ Group of Health Surveillance, Center of Pharmaceutical Studies, Faculty of Pharmacy, University of Coimbra, Polo III, Azinhaga de St ${ }^{a}$ Comba, 3000-548 Coimbra, Portugal ${ }^{b}$ INFARMED, I.P. - National Authority of Medicines and Health Products, 1749-004 Lisboa, Portugal

${ }^{c}$ Department of Pharmacology, Faculty of Pharmacy, University of Lisbon, Av. Prof. Gama Pinto, 1649-003 Lisboa, Portugal
\end{abstract}

\section{*Corresponding author:}

Group of Health Surveillance, Center of Pharmaceutical Studies, Faculty of Pharmacy, University of Coimbra

Pólo das Ciências da Saúde, Azinhaga de Santa Comba, 3000-548 Coimbra, Portugal.

Tel: +351239488400

Fax : +351239827126

\section{E-mail addresses:}

amptpereira@gmail.com (A.M.P.T. Pereira), ljgsilva@hotmail.com (L.J.G. Silva), cmlino@ff.uc.pt (C.M. Lino), leonor.meisel@infarmed.pt (L.Meisel), apena@ci.uc.pt (A. Pena) 


\begin{abstract}
The occurrence, fate, geographical and seasonal influence and environmental risk assessment of eleven of the most consumed pharmaceuticals in Portugal were studied in wastewater treatment plants (WWTPs) influents and (WWI) and effluents (WWE). WWI and WWE samples, from two sampling campaigns (spring and summer), in 2013, were evaluated in 15 different WWTPs across the country, by solid phase extraction (SPE) and liquid chromatography coupled with tandem mass detection (LC-MS-MS).

Lipid regulators were the most frequently found in WWI and WWE (184.1 and 22.3 mg/day/1000 inhab., respectively), followed by anti-inflammatories (1339.4 and 15.0 mg/day/1000 inhab., respectively), and antibiotics (330.7 and $68.6 \mathrm{mg} / \mathrm{day} / 1000$ inhab., respectively). Anxiolytics were the least detected with 3.3 and $3.4 \mathrm{mg} / \mathrm{day} / 1000$ inhab. in WWI and WWE, respectively.

The mass loads, both in WWI and WWE, were higher in summer than those found during the spring season, being remarkable the high values registered in a region where population triplicates in this time of the year. The mean removal efficiency achieved was of $94.5 \%$, nonetheless, between the different therapeutic groups, as well as within each group, important variations in removal were observed, going from not eliminated to $100 \%$. In the summer higher efficiencies were observed regarding lipid regulators and antibiotics.

Furthermore, an important outcome was the evaluation, by means of risk quotients (RQs), of the potential ecotoxicological risk posed by the selected pharmaceuticals to different aquatic organisms, exposed to the effluents studied. Ciprofloxacin, bezafibrate, gemfibrozil, simvastatin and diclofenac showed RQs higher than one, being expected that these pharmaceuticals might pose a threat to the three trophic levels (algae, daphnids and fish) evaluated. These results highlight the importance of these monitoring studies, as required by the Directive 2013/39/EU, in order to minimize their aquatic environmental contamination and support future prioritization measures.
\end{abstract}

\title{
Keywords
}

Environmental contaminants; pharmaceuticals; municipal wastewaters; occurrence and fate; seasonal variation; environmental risk assessment.

\section{Introduction}


Human pharmaceuticals represent a group of widely used chemicals that contaminate the environment. Albeit in trace amounts, they are of concern since they are designed to perform a biological effect. Moreover, given their continuous introduction into the environment, their environmental impact, both as stressors and as agents of change, is of great importance (Mompelat et al., 2009).

Worldwide has been recognized the environmental impact of medicinal products. Although no legal limits have been established in water, relevant legislation and regulatory guidance has been issued by the European Union (EU) (Verlicchi et al., 2014). The Water Framework Directive (WFD) (Directive 2000/60/CE), establishes the priority substances in the policies of the water domain of the EU (Afonso-Olivares et al., 2013; Vazquez-Roig et al., 2011), whereas, the Directive 2001/83/EC, as amended by the Directive 2004/27/EC, requires an evaluation of the potential environmental risks to be performed for every new marketing authorization. In January 2012, the EU published a report regarding the revision of the Directive 2000/60/CE, and several new substances were proposed, including diclofenac (European Commission 2012). Moreover, directive 2013/39/EU sets a watch list, that includes three pharmaceuticals, being one of them diclofenac, and requires relevant monitoring data from each member state, in order to minimize their aquatic environmental contamination and support future prioritization measures.

In recent years, has been observed an increased and chronic consumption of several medicines all across the world. In Portugal the highest prescription and consumption regard, among others, alprazolam, lorazepam and zolpidem (anxiolytics and hypnotics), azithromycin and ciprofloxacin (antibiotics), simvastatin, bezafibrate and gemfibrozil (lipid regulators), and ibuprofen, diclofenac and paracetamol (non-steroidal anti-inflammatories and analgesics) (INFARMED, 2011) (Table 1). As their use cannot be avoided, a sound risk assessment of their presence in the environment is a key problem. The selected pharmaceuticals were chosen within each group by the ranking of national sales, by package, in 2011 (INFARMED, 2011) (Table 1).

[Insert Table 1 about here]

The main source of pharmaceuticals residues in the aquatic environment is from human excretion, consequently, the widespread presence of pharmaceuticals in environmental samples is most likely to occur from wastewaters treatment plants (WWTPs), which incompletely remove these compounds. Pharmaceuticals are then released into the 
environment as parent compounds, metabolites, as well as transformation products formed during water treatments, by biodegradation, photolysis or hydrolysis (Petrovic and Barceló, 2007), leading to the contamination of surface waters, seawaters, groundwater and some drinking waters. Nevertheless, there are also other pathways of aquatic contaminations such as sewage overflow, aquaculture, and leaching from agricultural fields resulting from the spreading of manure and presence of livestock (Al Aukidy et al., 2012; Bueno et al., 2012; Fick and Söderström, 2009; Focazio et al., 2004; Jelic, 2012; Kümmerer, 2010; Nikolaou et al., 2007; Seifrtová et al., 2008).

Heavy contamination pressures from extensive urban activities characterize the Portuguese coast and main rivers that might lead to high aquatic contamination levels and consequent environmental and human exposure. Although the concentrations of pharmaceuticals in influents (WWI) and effluents (WWE) of WWTPs are routinely monitored in many countries, there is little knowledge on pharmaceuticals occurrence/fate, and their environmental exposure profile in Portugal (Loos et al., 2012; Salgado et al., 2012; Santos et al., 2013; Sousa et al., 2011). Moreover, their sources of contamination may be influenced by different geographical patterns of pharmaceuticals consumption, and important fluctuations due to seasonal variations might also occur.

These are important issues for an integrated management of the possible environmental risk assessment, which is essential for the implementation of minimizing measures. Frequently, a pragmatic approach for identifying hazards or prioritizing critical substances has been made (EMA, 2006), but this concept is not sufficiently precise for an accurate assessment of pharmaceuticals risk. Nevertheless, information on real measured concentrations of pharmaceuticals in the environmental aquatic compartment, allows a good insight into human exposure.

The key driving force of this study was to perform, for the first time, a nationwide environmental contamination mapping of the above mentioned 11 pharmaceuticals, in 15 WWTPs from 5 different Portuguese regions, in order to evaluate geographical/national contamination patterns and to assess vulnerable areas. Moreover, we aimed to assess seasonal influence, in spring and summer seasons, and WWTPs removal efficiency. Furthermore, an important outcome was the evaluation of the potential ecotoxicological risk posed by these pharmaceuticals to different aquatic organisms, when exposed to the studied WWEs, allowing a better understanding of the environmental risk in the Portuguese context.

\section{Materials and methods}




\subsection{Sampling site and collection}

WWIs and WWEs of 15 different WWTPs, located in 5 Portuguese regions, North, Center, Lisbon and Tagus Valley, Alentejo and Algarve (Figure 1), were collected. These WWTPs are designed for 6850 to 756000 population equivalents, representing $26.1 \%$ of the national population (10526700, in 2012). With average flow rates ranging between 349 and $140000 \mathrm{~m}^{3}$ per day, these facilities have their discharge points in the main Portuguese rivers and Atlantic Ocean. They treat domestic, hospital and industrial wastewaters, operating with secondary or tertiary treatments, as described in Table 2 .

[Insert Figure 1 about here]

[Insert Table 2 about here]

Sampling campaigns, carried out in 2013, were performed during two sampling periods; between 14 May/04 June - spring, and 11 July/14 August - summer, one sample by sampling site (WWI and WWE) for each season. The characterization of WWIs and WWEs, for the different sampling periods, is shown in Table S1 (Supporting information). WWIs and WWEs samples were collected in high-density polyethylene containers previously rinsed with bidistilled water, as time proportional 24-h composite samples. Samples, kept refrigerated (4 ${ }^{\circ} \mathrm{C}$ ) during the transport to the laboratory, upon reception, were frozen and stored at $-20{ }^{\circ} \mathrm{C}$ until analysis.

\subsection{Standards, Chemicals and Materials}

Pharmaceutical standards, with purity degree $\geq 98 \%$, were purchase from Fluka, Sigma and Riedel-de-Haen (Sigma-Aldrich, Spain), with exception for alprazolam, lorazepam and zolpidem that were acquired from LGC Standards (Barcelona, Spain). Individual stock solutions were prepared in methanol at $500 \mu \mathrm{g} \mathrm{mL^{-1 }}$ and stored at $-20{ }^{\circ} \mathrm{C}$ in the dark. An intermediate solution was prepared, in mixture, at a concentration of $5 \mu \mathrm{g} \mathrm{mL}^{-1}$, in methanol. Daily, a working solution at $0.5 \mu \mathrm{g} \mathrm{mL}^{-1}$, in methanol/water $(25: 75 \mathrm{v} / \mathrm{v})$, was used.

Internal standards (paracetamol-D4 and fluoxetine-D5) were added to the samples extracts at a final concentration of $500 \mu \mathrm{g} \mathrm{L}^{-1}$.

J.T. Baker (Deventer, Netherlands) supplied Baker-analyzed methanol for LC-MS and ultrapure Milli-Q water was obtained from a Milli-Q apparatus from Millipore (Molsheim, France). Formic acid (50\%) and hydrochloric acid (37\%) were obtained from Fluka, Sigma 
and Riedel-de-Haen (Sigma-Aldrich, Spain). Glass microfiber filters (1.0 $\mu \mathrm{m}, 934-\mathrm{AH})$ and 0.45 and $0.2 \mu \mathrm{m}$ polyamide membrane filters were aquired from Whatman Schleicher and Schuell (USA) and from Whatman, (Dassel, Germany), respectively. Oasis MAX (500mg, $6 \mathrm{~mL}$ ) cartridges, from Waters Corporation (Milford, Massachusetts, USA), were used for solid phase extraction (SPE).

\subsection{Experimental Procedure}

The method used for identification and quantification of these pharmaceuticals was based on the methodology reported by Sousa et al. (2011). Briefly, after defrosting and reaching room temperature, samples were acidified with hydrochloric acid (37\%) to $\mathrm{pH} 2$ and, to remove suspended material, consecutively filtrated through a glass microfiber filter, 0.45 and $0.2 \mu \mathrm{m}$ polyamide membrane filters.

For SPE the Oasis MAX cartridges were pre-conditioned with $6 \mathrm{~mL}$ methanol followed by 3 mL Milli-Q water at $\mathrm{pH} 2$. Samples (50 mL of WWI and $100 \mathrm{~mL}$ of WWE) were applied to the cartridge, with a flow of $10 \mathrm{~mL} \mathrm{~min}^{-1}$, that was then washed with $3 \mathrm{~mL}$ Milli-Q water. After left to dry for 15 minutes elution was performed with $2 \times 3 \mathrm{~mL}$ methanol. The eluent was evaporated to dryness at $45^{\circ} \mathrm{C}$ under a gentle stream of nitrogen and the residue was redissolved in $200 \mu \mathrm{L}$ of methanol/Milli-Q water (35:65 v/v).

Instrumentation analysis was performed in a liquid chromatography with tandem mass detection (LC-MS-MS) system equipped with two 210 HPLC pumps, a 500 MS ion trap mass spectrometer and a ProStar 410 autosampler kept at $10^{\circ} \mathrm{C}$, all from Varian (Walnut Creek, CA, USA). The system, assembled with a Varian analytical column Pursuit UPS C18 $(2.1 \mathrm{~mm}$ i.d.x50 mm, $2.4 \mathrm{~mm})$, kept at $35^{\circ} \mathrm{C}$, and a guard column of the same characteristics $(2.1 \mathrm{~mm}$ i.d.x10 mm, $3 \mathrm{~mm}$ ), was fitted with a $10 \mu \mathrm{L}$ sample loop. Chromatographic separation was achieved using a flow rate of $300 \mu \mathrm{L} \mathrm{min}^{-1}$ and a gradient of methanol and $10 \mathrm{mM}$ formic acid in Milli-Q water as follows: $25 \%$ methanol, rising to $75 \%$ methanol in $8 \mathrm{~min}$, then to $100 \%$ methanol at $10 \mathrm{~min}$ and holding until $13 \mathrm{~min}$; at the end of the chromatographic run the column re-equilibrated to the initial conditions in $1 \mathrm{~min}$ and stabilized for $8 \mathrm{~min}$.

The electrospray ionization (ESI) source parameters (ionization polarity, drying gas temperature, needle voltage and capillary voltage) and the detector storage and fragmentation conditions (RF loading voltage and collision induced dissociation (CID) voltage, precursor and product ions) are described in Table S2 (Supporting information). The software used for data processing was the Varian MS Workstation version 6.9.1. Identification of positive samples was made by comparison of the MS/MS spectra against authentic standards and also 
by setting two to three qualifiers and $20 \%$ tolerance criteria. Quantification of each compound was based on the main characteristic $\mathrm{MS}^{2}$ precursor/product ion transition.

\subsection{Mass loading estimations and removal efficiency}

Mass loadings of all pharmaceuticals were calculated for each sampling period by multiplying individual concentrations of each pharmaceutical found by the mean daily flow rate of wastewater provided by each WWTP (Table S1, Supporting information). The WWTPs loads were normalized by the population equivalent (Table S1, Supporting information). Removal efficiency of the selected pharmaceuticals was evaluated by means of Eq. (1):

$$
\text { Removal efficiency }(\%)=\frac{\operatorname{minf}-\operatorname{meff}}{\operatorname{minf}} \times 100
$$

Where minf is the load of pharmaceutical in WWI and meff is the load of pharmaceutical in WWE (Santos et al., 2013).

\subsection{Ecotoxicological risk assessment}

The risk assessment for the aquatic compartment has been based on the guideline on the environmental risk assessment of medicinal products for human use (EMEA, 2006). Following this guideline, the risk quotients (RQs) associated to the selected pharmaceuticals were calculated by the ratio of measured environmental concentration (MEC) and predicted no-effect concentration (PNEC).

The maximum individual concentrations of pharmaceuticals found in the 30 different WWEs were used as MEC, to set a worst case scenario approach (Santos et al., 2013; Vazquez-Roig et al., 2012). PNEC values were calculated by applying an uncertainty factor (UF) of 10 to the long-term no-observed-effect-concentration (NOEC) values or of 50 and 1000, to the shortterm lowest-observed-effect-concentration (LOEC) and $\mathrm{L}(\mathrm{E}) \mathrm{C} 50$ values, respectively, available in the literature. The UF is an expression of the degree of uncertainty in the extrapolation from the test data on a limited number of species to the actual environment (EMEA, 2006). When no experimental data were available, L(E)C50 values were estimated with ECOSAR 1.11. If $\mathrm{RQ}$ is equal or above 1 there is a potential environmental risk situation, whereas when values are lower than 1 , no risk is expected.

\section{Results and discussion}




\subsection{Method validation}

Revalidation was performed, to assure the fitness for purpose of the multi-residue analytical method for the determination of the selected pharmaceuticals in wastewaters (Table S3, Supporting information). Several procedures were carried out in WWI and WWE samples, encompassing sensitivity, linear range, matrix effects accuracy and precision features, according to Sousa et al. (2011).

Linearity, achieved for every compound, in triplicate, in the concentration range from 0.01 to $2 \mu \mathrm{g} \mathrm{L} \mathrm{L}^{-1}$, was good, as shown by the correlation coefficients $\left(r^{2}\right)$ observed, ranging from 0.9926 to 0.9992 .

The method detection limits (MDLs), and the method quantification limits (MQLs) were estimated as the concentration giving a signal-to-noise $(\mathrm{S} / \mathrm{N})$ ratio of 3 and 10 , respectively, are within the range of other methods developed for the same purpose (Ashton et al., 2004; Gros et al., 2013, 2006; Kummerer, 2004; López-Serna et al., 2010; Petrovic et al., 2006; Salgado et al., 2010; Suominen, 2013; Ternes et al., 2001; Weigel et al., 2004; Yuan et al., 2012). MDL values ranged from 0.4 to $60.0 \mathrm{ng} \mathrm{L}^{-1}$ in WWE and from 0.5 to 61.2 in WWI. MQL ranged from 1.4 to $200.0 \mathrm{ng} \mathrm{L}^{-1}$ in WWE and from 1.7 to $204.1 \mathrm{ng} \mathrm{L}^{-1}$ in WWI.

Recovery tests were performed to determine the accuracy and precision of the method by spiking of WWI and WWE samples. Precision was evaluated through the RSD (\%) of the fortified samples. Recoveries were all above $65.2 \%$ and relative standard deviation ranged from 5.9 to $23.0 \%$.

\subsection{Occurrence and geographical variations}

\subsubsection{Frequency and occurrence}

Table 3, Figure 2, and Table S4 (Supporting information) present the occurrence data of the selected pharmaceuticals in the WWI and WWE samples, their frequency, range, and mean concentration, together with the estimated mass loads of each compound and the removal efficiencies observed. Generally, the results showed that, as expected, the frequencies of contamination, concentration levels and mass loads, were higher in WWI samples, although some exceptions were observed. From the 11 targeted pharmaceuticals, only two, alprazolam and zolpidem, were not detected, being all samples were contaminated with at least one, and up to 8 pharmaceuticals.

[Insert Table 3 about here] 
[Insert Figure 2 about here]

Anti-inflammatories, found in WWI and WWE samples with a frequency of $84 \%$ and $30 \%$, respectively, reached the highest average concentration level in WWI samples, up to 9837.2 ng L $\mathrm{L}^{-1}$, corresponding to a mean mass load of $1339.4 \mathrm{mg} /$ day/1000 inhab.. Paracetamol, with the highest average WWI frequency (100\%) and average concentration level, $25935.1 \mathrm{ng} \mathrm{L}^{-1}$ (3536.0 mg/day/1000 inhab.), accounted for the highest concentration, among all pharmaceuticals, in WWTP 14, with $66700.0 \mathrm{ng} \mathrm{\textrm {L } ^ { - 1 }}$ (16900.2 $\mathrm{mg} /$ day/1000 inhab.). Diclofenac had the lowest WWI frequency (54\%) and average concentration $125.2 \mathrm{ng} \mathrm{L}^{-1}$ (27.4 mg/day/1000 inhab.).

Antibiotics accounted with $32 \%$ of positive samples, in WWI, with ciprofloxacin having the highest frequency, 57\%. Their average contamination level reached up to $2208.0 \mathrm{ng} \mathrm{L}^{-1}$ (330.7 $\mathrm{mg} /$ day/1000 inhab.), with ciprofloxacin accounting with the second highest average concentration, $4373.6 \mathrm{ng} \mathrm{L}^{-1}$ (654.2 mg/day/1000 inhab.), among all pharmaceuticals. The highest concentrations in WWE was observed for antibiotics, with $615.7 \mathrm{ng} \mathrm{L}^{-1}$ (68.6 $\mathrm{mg} /$ day/1000 inhab.), being ciprofloxacin the most prevalent compound, with $1224.7 \mathrm{ng} \mathrm{L}^{-1}$ (136.8 mg/day/1000 inhab.).

Concerning the lipid regulators, the therapeutic group most widely detected (94\% in WWI, and $68 \%$ for WWE), a mean concentration of $1440.0 \mathrm{ng} \mathrm{L}^{-1}(184.1 \mathrm{mg} / \mathrm{day} / 1000$ inhab.) was found, with simvastatin and bezafibrate having higher averages than gemfibrozil.

Anxiolytics were the group that presented the lowest frequency $(17 \%$, both in WWI and WWE) with an average concentrations of $26.9 \mathrm{ng} \mathrm{L}^{-1}\left(3.3 \mathrm{mg} /\right.$ day/1000 inhab.) and $28.2 \mathrm{ng} \mathrm{\textrm {L } ^ { - }}$ ${ }^{1}$ (3.4 mg/day/1000 inhab.), for WWI and WWE, respectively, being lorazepam the only one found.

\subsubsection{Comparison with national consumption and excretion data}

The results found in our study are largely explained by consumption and excretion data. The latest Portuguese figures on pharmaceuticals consumption are from 2011 and were reported by INFARMED, the National Authority of Medicines and Health Products. The group of antiinflammatories, with excretion rates ranging from 5\% to 39\% (Al Aukidy et al., 2012; Mompelat et al., 2009), is the one with higher sales ranking, with a total of 6598258 packages sold, with the decreasing rank order: paracetamol $>$ ibuprofen $>$ diclofenac (INFARMED, 2011), that equals the ranking of WWI average mass loads found in our study: 3536.0, 454.8 and $27.3 \mathrm{mg} / \mathrm{day} / 1000$ inhab., respectively (Table 1 and Table 3). 
Anxiolytics are the second group in the ranking of national sales, with 5420633 packages sold (INFARMED, 2011), however, due to their negligible excretion rates (Mompelat et al., 2009; Sousa et al., 2011) they presented low WWI mass loads (Table 1 and Figure 2).

Regarding lipid regulator, bezafibrate has the lower selling rates from all of the selected pharmaceuticals; however, it has high excretion rates (up to 69\%) and higher stability than most of the studied compounds, which led to WWI mean mass loads of $171.6 \mathrm{mg} / \mathrm{day} / 1000$ inhab., approximately half than simvastatin mass loads $(323.7 \mathrm{mg} /$ day/1000 inhab.), the bestselling pharmaceutical (with 3440703 packages), but with only 15\% of the consumed dose being released in the environment in his original form (Al Aukidy et al., 2012; Mompelat et al., 2009).

Although lipid regulators present higher selling rates than antibiotics, 3482153 and 1562978 packages, respectively (INFARMED, 2011), they show lower WWI mass loads (Table 1 and Figure 2). This fact is due to the lower excretion rates of the former, specially of simvastatin when compared with the excretion of up to $84 \%$ of ciprofloxacin (Al Aukidy et al., 2012; Mompelat et al., 2009).

\subsubsection{Geographical variations}

Despite the fact that some efforts were made for a better understanding of the pharmaceuticals fate in Portuguese WWTPs, specific geographical surveys must be considered, since the occurrence pattern of pharmaceuticals in WWTPs is normally related to local consumption or sales figures (Sousa et al., 2011). On the other hand, it is necessary to determine whether observations made from geographical sampling sets, are representative of environmental concentrations nationwide, being essential to perform contamination maps (Santos et al., 2013; Sousa et al., 2011).

Portugal is a known vacation destination, in particular Algarve, where in summer, the number of inhabitants triplicates, and the population-equivalent served during this period is much higher than the annual average, increasing the overall flow rates (Table S1, Supporting information), and promoting the highest mass load determined (36152.2 mg/day/1000 inhab.). The results for the remaining regions are comparable, with Lisbon (12178.5 and 25777.1 $\mathrm{mg} /$ day/1000 inhab., in spring and summer, respectively) and North (12533.0 and 25945.0 mg/day/1000 inhab., in spring and summer, respectively) regions, presenting slight higher contamination values than Alentejo (9298.1 and $10081.1 \mathrm{mg} /$ day/1000 inhab., in spring and summer, respectively) and Center (7109.4 and $7203.5 \mathrm{mg} /$ day/1000 inhab., in spring and summer, respectively) region (Figure 3). 
[Insert Figure 3 about here]

For management purposes, information on the distribution of risk due to pharmaceuticals use on a geographical scale and a risk assessment based in a geographic information system can be very useful for an environmental-oriented monitoring (Hernando et al., 2011).

\subsubsection{Comparison with other studies}

The range of contamination levels, both in WWI and WWE samples, concur with those found in several other studies reported worldwide. As in our study, others report that antiinflammatories, the most investigated therapeutic group, present the highest WWI concentration levels. Accordingly, paracetamol shows the highest WWI values (up to 150000 ng $\mathrm{L}^{-1}$ ), and much lower WWE levels. Moreover, ibuprofen WWI average contamination is also above than that reported for diclofenac, and the majority of the results conveyed for WWE samples presented the same tendency (Behera et al., 2011; Crouse et al., 2012; GraciaLor et al., 2012; Miège et al., 2009; Petrovic et al., 2006; Roberts and Thomas, 2006; Sim et al., 2011; Verlicchi et al., 2012). This pattern was also observed, by an EU wide monitoring survey on WWE samples recently published (Loos et al., 2012). Comparatively to previous Portuguese findings, paracetamol was also found in WWI at much higher concentration values than in WWE (Santos et al., 2013; Sousa et al., 2011), and the concentration range of ibuprofen, in WWI was also similar with the present findings (ranging from 550 to $9102 \mathrm{ng} \mathrm{\textrm {L } ^ { - }}$

1) (Salgado et al., 2011; Santos et al., 2013; Sousa et al., 2011), nonetheless, higher values were reported for WWE (ranging from 119 to 1250) (Loos et al., 2012; Santos et al., 2013; Sousa et al., 2011).

Concerning lipid regulators, limited studies have examined the occurrence and fate of simvastatin and, on the contrary to our study, in which simvastatin presented an average concentration of $2652.1 \mathrm{ng} \mathrm{L}^{-1}$, lower concentrations, below $10 \mathrm{ng} \mathrm{L}^{-1}$, were reported, both for WWI and WWE (Verlicchi et al., 2012). Conversely to our study, comparable concentrations of gemfibrozil and bezafibrate, or even higher concentrations of gemfibrozil than bezafibrate were reported, in WWE (Loos et al., 2012). Nonetheless, our results are in good agreement with other scientific literature (Gracia-Lor et al., 2012; Loos et al., 2012; Miège et al., 2009; Verlicchi et al., 2012), including the Portuguese available data (Santos et al., 2013; Sousa et al., 2011). 
In relation to antibiotics, concurring with our data, ciprofloxacin is usually reported at higher concentrations when compared to azithromycin (Gros et al., 2013; Miège et al., 2009; Petrovic et al., 2006; Verlicchi et al., 2012; Watkinson et al., 2009). In contrast to our findings (4373.6 ng $\mathrm{L}^{-1}$ and $1224.7 \mathrm{ng} \mathrm{L}^{-1}$, in WWI and WWE, respectively), lower average concentrations of ciprofloxacin have been reported, $1600 \mathrm{ng} \mathrm{L}^{-1}$ and $860 \mathrm{ng} \mathrm{L}^{-1}$, for WWI and WWE samples, respectively (Verlicchi et al., 2012). Antibiotics are the group that presents larger national differences. For instance, the measured concentrations of ciprofloxacin in the studied WWI and WWE samples were found at higher levels (up to 17500.0 and $9800.0 \mathrm{ng} \mathrm{L}^{-}$ 1, respectively) than other previous findings (up to 667 and $369 \mathrm{ng} \mathrm{L}^{-1}$, respectively) (Loos et al., 2012; Santos et al., 2013; Seifrtová et al., 2008; Sousa et al., 2011). As for azithromycin,

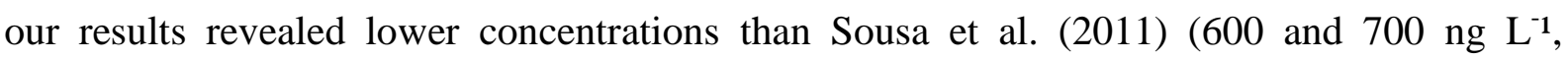
respectively) and Santos et al. (2013) (186 and $171 \mathrm{ng} \mathrm{L}^{-1}$, respectively).

As for anxiolytics, results similar to ours were retrieved by other Portuguese and international studies, where low concentration values were found in WWI and WWE (up to 299 and $300 \mathrm{ng}$ $\mathrm{L}^{-1}$, respectively) (Gracia-Lor et al., 2012; Loos et al., 2012; Santos et al., 2013; Sousa et al., 2011; Verlicchi et al., 2012; Yuan et al., 2012). The highest level found for lorazepam in a WWI of a WWTP of a psychiatric hospital was 294 ng L ${ }^{-1}$ (Yuan et al., 2013). As in our research, lorazepam, is found in higher frequencies and concentrations than alprazolam and zolpidem (Gracia-Lor et al., 2012; Yuan et al., 2013). The EU WWE average concentrations of alprazolam and zolpidem, evaluated by Loos et al. (2012), was also very low, 1 and $2 \mathrm{ng} \mathrm{L^{- }}$ 1, with maximum concentrations of 33 and $43 \mathrm{ng} \mathrm{L}^{-1}$, respectively.

\subsection{Removal efficiency}

In the present study, the fate of the selected pharmaceuticals was determined in 15 Portuguese WWTPs employing different treatment processes (e.g. secondary and tertiary treatments, with UV). The WWTPs were operating normally during all sampling events, and generally achieved good removals on what concerns biochemical oxygen demand (BOD), chemical oxygen demand (COD) and total suspended solids (TSS) (Table S1, Supporting information). As seen in Table 2, systems that use an activated sludge process are still widely employed for wastewater treatment, mostly because they produce an acceptable quality WWE at reasonable operating and maintenance costs. However, this type of treatment capability of removing pharmaceuticals is limited, depending on influent concentration and on biological reactor configuration (sequence of anaerobic aerobic and anoxic compartments) (Gros et al., 2009; Kasprzyk-Hordern et al., 2009; Vazquez-Roig et al., 2012; Wick et al., 2009). In fact, 
generally, the overall results showed that the 15 WWTPS studied, despite some differences in the treatments applied, WWTPs were not able to completely remove these pharmaceuticals, exhibiting a comparable performance in their removal, in mean values of 94.5\% (Table 3 and Table S4, Supporting information).

Nonetheless, it is noticeable a great variation in removal efficiencies between the different therapeutic groups (Figure 4), as well as within each group, going from not eliminated to $100 \%$, and no association was establish between the decreased BOD, COD and TSS in WWE and removal percentage (Table 3 and S1, Supporting information).

[Insert Figure 4 about here]

Anti-inflammatories were the group most efficiently removed (98.9\%) (Figure 4), mostly due to the high removal rates of paracetamol, with an average of $99.9 \%$. Diclofenac was the one with lower removal efficiency, with an average of $45.6 \%$ (Table 3). Considerable high removal efficiencies were observed for lipid regulators and antibiotics, $87.9 \%$ and $79.3 \%$ respectively. As for anxiolytics, lorazepam was not eliminated, although it was the pharmaceutical with the lowest WWI mass loads. In some WWTPscases, lorazepam, azithromycin, ciprofloxacin, gemfibrozil, simvastatin and diclofenac had higher concentrations in WWE than in WWI (Table S4, Supporting information). Two possible explanations are that over the treatment process, conversion of their conjugated metabolites to the original substances, takes place and also changes in the adsorption behavior to particles during the treatment process (Bueno et al., 2012; Sousa et al., 2011).

Our findings are in agreement with previous studies found in the scientific literature, where incomplete removal of a wide range of pharmaceuticals in conventional WWTPs has been described (Al Aukidy et al., 2012; Behera et al., 2011; Castiglioni et al., 2006; Jelic et al., 2011; Santos et al., 2013; Sousa et al., 2011).

These results also allow evaluating which WWTPs release more pharmaceuticals into the aquatic environment (by multiplying the concentrations found by the daily flow rate) and inferring the possible risk for the receiving water. These data revealed that WWTP 11 released, per day, in the summer, $429 \mathrm{~g}$ of the selected pharmaceuticals in the surrounding aquatic environment, followed by WWTP 7 and 6, with 213 and $155 \mathrm{mg}$, respectively. It should also be noted, that WWTP 7 released $178 \mathrm{~g}$ per day of antibiotics, the group with higher contamination values, into the receiving aquatic compartment, with all the problems associated concerning the emergence of bacterial resistances. These results translate the 
consumption pattern and number of the population served by each WWTP and removal efficiencies of each WWTP, and as expected higher values were obtained for WWTPs that serve higher populations.

Although, pharmaceuticals concentrations in sludge or suspended solids was not considered nor measured, one should note that good removal rates obtained in aqueous phase do not imply degradation to the same extent (Jelic et al., 2011; Xu et al., 2007). Moreover, the conversion of a given pharmaceutical to transformation products other than the analyzed might lead to lower pharmaceutical levels in WWE samples, and to an apparent removal (Gracia-Lor et al., 2012; Jelic et al., 2011). For instance, metabolites of diclofenac (Vieno and Sillanpää, 2014; Zenker et al., 2014) and a phototransformation product, more toxic than the parent compound, were already detected in the environment (Escher and Fenner, 2011).

\subsection{Seasonal variation}

During summer, in some areas, like Algarve, the population increases and this reflects on the flow rate of some WWTPs (Table S1, Supporting information). However, in other regions, like Alentejo, the flow rate decreases, a fact that can be explained by the reduced precipitation typical of this period, this fact is explained by the combined sewer, sewage that includes both anthrophic discharges and rain water, that is common in Portuguese WWTPs, (IPMA, 2014). These facts might be responsible by the results obtained in our study, where the sum of mass loads in WWI for summer was $7010.6 \mathrm{mg} /$ day/1000 inhab., higher than that found during the spring season, $3472.3 \mathrm{mg} /$ day/1000 inhab. (Figure 2). This pattern was observed not only in WWI, but also in WWE samples, with 437.2 and $81.2 \mathrm{mg} /$ day/1000 inhab., for spring and summer, respectively, and was similar to all therapeutic groups, with the exception of anxiolytics.

Regarding the obtained results for each pharmaceutical, our data are in agreement with other studies, where higher levels of some pharmaceuticals, such as diclofenac, ibuprofen, paracetamol, gemfibrozil, were found in summer (Bueno et al., 2012; Loraine and Pettigrove, 2006; Sui et al., 2011; Sun et al., 2013). Conversely, other authors observed any variation between seasons for diclofenac, ibuprofen, paracetamol, bezafibrate and gemfibrozil (GraciaLor et al., 2012); or even observed lower concentrations in the summer, for ibuprofen and bezafibrate (Vieno et al. 2005, Sui et al. 2011).

Many factors including solids retention time (SRT), organic load, microbial community, raw sewage temperature and $\mathrm{pH}$ were shown to have pronounced effects on the efficiency of activated sludge treatments (Lajeunesse et al., 2012). As such, seasonal variations may also 
affect the treatment efficiency of WWTPs, leading to concentration variations of pharmaceuticals in the WWE. Generally, in spring the microbial activity and biological reactions are reduced due to lower temperatures and dilution effects, leading to a lower removal efficiency (Azzouz and Ballesteros, 2013; Lajeunesse et al., 2012; Verlicchi et al., 2012; Vieno et al., 2005). In fact, regarding lipid regulators and antibiotics lower removal efficiencies were observed in spring (36.2\% and $47.2 \%$ respectively) than in summer $(89.3 \%$ and $79.8 \%$ respectively), corroborating the expected tendency (Figure 4). However, antiinflammatories presented similar removal percentages, $99.1 \%$ and $98.7 \%$, for spring and summer, respectively that translated into a higher mean removal in spring when compared to summer (Figure 4). As for anxiolytics, they were only found in the spring season and in low concentrations, not providing enough data for any seasonal comparison.

Although the overall results indicate that removal efficiency was higher in the spring season, this is due to the small difference in the percentage of removal group of anti-inflammatories, that has mass loads exceptionally higher than the others do, strongly influencing the average removal results.

\subsection{Environmental risk assessment}

The above-mentioned data about occurrence and fate of several pharmaceuticals is crucial in order to improve ERA in a way to evaluate health, ecological and economic consequences. Since pharmaceuticals concentration in water is low, ecotoxicological long-term data are preferred to short-term data. However, due to the lack of long-term toxicological studies, a widespread approach is the use of data from short-term studies (EC50 or LC50) to calculate PNECs (Santos et al., 2013; Vazquez-Roig et al., 2012). It should be taken into account that the choice of data can obviously affect the outcome and that only 30 samples (15 WWTPs in each seasons) were used. The highest concentrations of pharmaceuticals in the WWE samples (to set in the worst-case scenario) (Santos et al., 2013; Vazquez-Roig et al., 2012), PNEC values (together with UFs) and RQs deemed for each analyte are shown in Table 4.

The low resulting PNEC values could be explained by these compounds high biological activity and bioconcentration, being detected in biota tissues in higher concentrations than in the aquatic environment.

[Insert Table 4 about here] 
According to these results, the pharmaceuticals ciprofloxacin, bezafibrate, gemfibrozil, simvastatin and diclofenac showed RQs higher than one, in the range of 1.043 to 115.563 , for at least one trophic level, posing a risk to algae, daphnids and fish. Although all the other RQs were values lower than 1 , a certain risk could be expected for the substances with a RQ between 0.1 and 1, including, in this way, all the other pharmaceuticals that were detected in WWE, regarding at least one trophic level (Vazquez-Roig et al., 2012) (Table 4).

In accordance with these findings, it could be concluded that due to the incomplete removal of pharmaceuticals in WWTPs, their WWEs would represent a threat to aquatic ecosystems and probably the dilution of wastewaters in receiving surface waters may not be enough, to mitigate their ecotoxicological risk.

The approach followed in this work is only focused on the ecotoxicity that individual pharmaceuticals may cause to aquatic organisms. However, in the aquatic environment they are present as a mixture of different therapeutic groups, their metabolites and transformation products, which may have synergic or additive effects, exhibiting higher toxicities than single compounds, even at lower concentrations, as was shown by some authors, being the real hazard greater than the calculated (Richards et al., 2004; Santos et al., 2013, 2010; Yang et al., 2008).

This risk evaluation has its limitations, such as the lack of more long-term toxicological studies and the unfeasibility to carry out chronic studies during the lifespan of the organisms (especially in fishes).

\section{Conclusions}

These findings allow concluding that pharmaceuticals are ubiquitous in Portuguese WWTPs, both in WWIs and WWEs, and their systematic prevalence in WWEs leads to the continuous exposure, even if in some cases at low levels, of the aquatic wildlife to these compounds.

With exception for alprazolam and zolpidem, pharmaceuticals were found up to $66700.0 \mathrm{ng}$ $\mathrm{L}^{-1}$ and 9800.0 ng L $\mathrm{L}^{-1}$, in WWI and WWE, respectively. Mass loads were found in WWI, as following, in the decreasing order: anti-inflammatories, antibiotics, lipid regulators and anxiolytics. As for WWE the order was: antibiotics, lipid regulators, anti-inflammatories and anxiolytics.

Some geographical differences were observed, mainly due to the increased population in Algarve during the summer. In fact, during the summer higher mass loads were observed, as a consequence of the increased number of tourists. Removal efficiencies were similar for all WWTPs, however anti-inflammatories had higher removal efficiencies than the other 
therapeutic groups, specially as a result of the high removal efficiency for paracetamol. As expected, excepting for anti-inflammatories, better removal efficiencies were observed in the summer.

Environmental risk assessment, using worst case scenario approach, showed that nine out of the eleven pharmaceuticals had RQ above 0.1, and five presented RQ over 1. Furthermore, ciprofloxacin, gemfibrozil, simvastatin and diclofenac exhibited RQs superior to 1, even when the average measured concentrations were used. These results underline that the aquatic ecosystem may be threatened.

As the use of pharmaceuticals cannot be avoided, these results highlight the importance of these monitoring studies, as required by the Directive 2013/39/EU, in order to minimize their aquatic environmental contamination and support future prioritization measures.

\section{Acknowledgements}

The authors thank FCT the financial support, through the project PTDC/AACAMB/120889/2010 and the fellowship granted to L.J.G. Silva (SFRH/BPD/62877/2009).

The authors are also grateful to Instituto da Água da Região do Norte (IAREN) of Portugal, for the MS analyses. Finally, we gratefully acknowledge every person from the groups Águas de Portugal, Águas de Gaia and Águas da Figueira, S.A., who provided their technical assistance in collecting the wastewater samples.

\section{References}

Afonso-Olivares, C., Torres-Padrón, M., Sosa-Ferrera, Z., Santana-Rodríguez, J., 2013. Assessment of the Presence of Pharmaceutical Compounds in Seawater Samples from Coastal Area of Gran Canaria Island (Spain). Antibiotics 2, 274-287.

Al Aukidy, M., Verlicchi, P., Jelic, a, Petrovic, M., Barcelò, D., 2012. Monitoring release of pharmaceutical compounds: occurrence and environmental risk assessment of two WWTP effluents and their receiving bodies in the Po Valley, Italy. Sci. Total Environ. $438,15-25$.

Ashton, D., Hilton, M., Thomas, K. V, 2004. Investigating the environmental transport of human pharmaceuticals to streams in the United Kingdom. Sci. Total Environ. 333, 16784.

Azzouz, A., Ballesteros, E., 2013. Influence of seasonal climate differences on the pharmaceutical, hormone and personal care product removal efficiency of a drinking water treatment plant. Chemosphere 93, 2046-54. 
Behera, S.K., Kim, H.W., Oh, J.-E., Park, H.-S., 2011. Occurrence and removal of antibiotics, hormones and several other pharmaceuticals in wastewater treatment plants of the largest industrial city of Korea. Sci. Total Environ. 409, 4351-60.

Bueno, M.J.M., Gomez, M.J., Herrera, S., Hernando, M.D., Agüera, a, Fernández-Alba, a R., 2012. Occurrence and persistence of organic emerging contaminants and priority pollutants in five sewage treatment plants of Spain: two years pilot survey monitoring. Environ. Pollut. 164, 267-73.

Castiglioni, S., Bagnati, R., Fanelli, R., Pomati, F., Calamari, D., Zuccato, E., 2006. Removal of pharmaceuticals in sewage treatment plants in Italy. Environ. Sci. Technol. 40, $357-$ 63.

Crouse, B. a, Ghoshdastidar, A.J., Tong, A.Z., 2012. The presence of acidic and neutral drugs in treated sewage effluents and receiving waters in the Cornwallis and Annapolis River watersheds and the Mill CoveSewage Treatment Plant in Nova Scotia, Canada. Environ. Res. 112, 92-9.

Dahl, U., Gorokhova, E., Breitholtz, M., 2006. Application of growth-related sublethal endpoints in ecotoxicological assessments using a harpacticoid copepod. Aquat. Toxicol. $77,433-8$.

Dave, G., Herger, G., 2012. Determination of detoxification to Daphnia magna of four pharmaceuticals and seven surfactants by activated sludge. Chemosphere 88, 459-66.

DeLorenzo, M.E., Fleming, J., 2008. Individual and mixture effects of selected pharmaceuticals and personal care products on the marine phytoplankton species Dunaliella tertiolecta. Arch. Environ. Contam. Toxicol. 54, 203-210.

Ebert, I., Bachmann, J., Kühnen, U., Küster, A., Kussatz, C., Maletzki, D., Schlüter, C., 2011. Toxicity of the fluoroquinolone antibiotics enrofloxacin and ciprofloxacin to photoautotrophic aquatic organisms. Environ. Toxicol. Chem. 30, 2786-92.

EMA, 2006. EU guideline Doc. Ref. EMEA/CHMP/SWP/4447/00. Available at: http://www.ema.europa.eu/docs/en_GB/document_library/Scientific_guideline/2009/10/ WC500003978.pdf. Accessed on 09.07.2014, 2006.

EMEA, 2006. Guideline on the environmental risk assessment of medicinal products for human use. London.

Escher, B.I., Fenner, K., 2011. Recent advances in environmental risk assessment of transformation products. Environ. Sci. Technol. 45, 3835-47.

Ferrari, B., Paxéus, N., Lo Giudice, R., Pollio, A., Garric, J., 2003. Ecotoxicological impact of pharmaceuticals found in treated wastewaters: study of carbamazepine, clofibric acid, and diclofenac. Ecotoxicol. Environ. Saf. 55, 359-70.

Fick, J., Söderström, H., 2009. Contamination of surface, ground, and drinking water from pharmaceutical production. Environ. Toxicol. Chem. 28, 2522-2527. 
Focazio, M.J., Kolpin, D.W., Furlong, E.T., 2004. Occurrence of human pharmaceuticals in water resources of the United States: a review, in: Pharmaceuticals in the Environment: Sources, Fate, Effects and Risks. Berlin, Germany. Springer Berlin Heidelberg, pp. 91105.

Gracia-Lor, E., Sancho, J. V, Serrano, R., Hernández, F., 2012. Occurrence and removal of pharmaceuticals in wastewater treatment plants at the Spanish Mediterranean area of Valencia. Chemosphere 87, 453-62.

Gros, M., Petrović, M., Barceló, D., 2006. Development of a multi-residue analytical methodology based on liquid chromatography-tandem mass spectrometry (LC-MS/MS) for screening and trace level determination of pharmaceuticals in surface and wastewaters. Talanta 70, 678-90.

Gros, M., Petrović, M., Barceló, D., 2009. Tracing pharmaceutical residues of different therapeutic classes in environmental waters by using liquid chromatography/quadrupolelinear ion trap mass spectrometry and automated library searching. Anal. Chem. 81, 898912.

Gros, M., Rodríguez-Mozaz, S., Barceló, D., 2013. Rapid analysis of multiclass antibiotic residues and some of their metabolites in hospital, urban wastewater and river water by ultra-high-performance liquid chromatography coupled to quadrupole-linear ion trap tandem mass spectrometry. J. Chromatogr. A 1292, 173-88.

Haap, T., Triebskorn, R., Köhler, H.-R., 2008. Acute effects of diclofenac and DMSO to Daphnia magna: immobilisation and hsp70-induction. Chemosphere 73, 353-9.

Henschel, K.P., Wenzel, a, Diedrich, M., Fliedner, a, 1997. Environmental hazard assessment of pharmaceuticals. Regul. Toxicol. Pharmacol. 25, 220-5.

Hernando, M.D., Rodríguez, A., Vaquero, J.J., Fernández-Alba, A.R., García, E., 2011. Environmental Risk Assessment of Emerging Pollutants in Water: Approaches Under Horizontal and Vertical EU Legislation. Crit. Rev. Environ. Sci. Technol. 41, 699-731.

Hoeger, B., Köllner, B., Dietrich, D.R., Hitzfeld, B., 2005. Water-borne diclofenac affects kidney and gill integrity and selected immune parameters in brown trout (Salmo trutta $\mathrm{f}$. fario). Aquat. Toxicol. 75, 53-64.

INFARMED, 2011. Monitorization of the Market. Available at: http://www.infarmed.pt/portal/page/portal/INFARMED/MONITORIZACAO_DO_MER CADO/OBSERVATORIO/ESTATISTICA_DO_MEDICAMENTO/EstMed-2011.pdf. Accessed on 04.09.2013, 2011.

IPMA, 2014. Available at: http://www.ipma.pt/pt/oclima/observatorio.secas/pdsi/monitorizacao/evolucao/. Accessed on 09.07.2014, 2014.

Isidori, M., Nardelli, A., Pascarella, L., Rubino, M., Parrella, A., 2007. Toxic and genotoxic impact of fibrates and their photoproducts on non-target organisms. Environ. Int. 33, 635-41. 
Jelic, A., 2012. Occurrence and fate of pharmaceuticals in wastewater treatment processes. Available at:

http://www.google.pt/url?sa=t\&rct=j\&q=\&esrc=s\&source=web\&cd=6\&cad=rja\&uact=8 \&ved=0CFUQFjAF\&url=http $\% 3 \mathrm{~A} \% 2 \mathrm{~F} \% 2 \mathrm{Fwww} . t \mathrm{x}$. cat $\% 2 \mathrm{Fbitstream} \% 2 \mathrm{Fhandle} \% 2 \mathrm{~F} 1$ 0803\%2F98403\%2FJELIC_PhD_THESIS.pdf\%3Bjsessionid\%3D2C52510DB2353A1E D66F117C9602A04C.tdx2\%3Fsequence\%3D1\&ei=2Eq9U7X_EuOn0QWG6oGABw\& usg=AFQjCNH5v8TCMeCWi0EMmkQu5nQPinGbhQ\&sig2=92On4WD5lKE9dRArtw yrrw\&bvm=bv.70138588,d.bGQ. Accessed on 09.07.2014, 2012.

Jelic, A., Gros, M., Ginebreda, A., Cespedes-Sánchez, R., Ventura, F., Petrovic, M., Barcelo, D., 2011. Occurrence, partition and removal of pharmaceuticals in sewage water and sludge during wastewater treatment. Water Res. 45, 1165-76.

Kasprzyk-Hordern, B., Dinsdale, R.M., Guwy, A.J., 2009. Illicit drugs and pharmaceuticals in the environment--forensic applications of environmental data, Part 2: Pharmaceuticals as chemical markers of faecal water contamination. Environ. Pollut. 157, 1778-86.

Kummerer, K., 2004. Pharmaceuticals in the Environment: Source, fate effect and risks. Springer Berlin Heidelberg.

Kümmerer, K., 2010. Pharmaceuticals in the Environment. Annu. Rev. Environ. Resour. 35, $57-75$.

Lajeunesse, a, Smyth, S. a, Barclay, K., Sauvé, S., Gagnon, C., 2012. Distribution of antidepressant residues in wastewater and biosolids following different treatment processes by municipal wastewater treatment plants in Canada. Water Res. 46, 5600-12.

Loos, R., Carvalho, R., Comero, S., António, D.C., Ghiani, M., Lettieri, T., Locoro, G., Paracchini, B., Tavazzi, S., Gawlik, B.M., Voorspoels, S., Schwesig, D., 2012. EU Wide Monitoring Survey on Waste Water Treatment Plant Effluents. Available at: http://publications.jrc.ec.europa.eu/repository/bitstream/111111111/26927/1/lb-na25563-en.pdf.pdf. Accessed on 09.07.2014, 2012.

López-Serna, R., Pérez, S., Ginebreda, A., Petrović, M., Barceló, D., 2010. Fully automated determination of 74 pharmaceuticals in environmental and waste waters by online solid phase extraction-liquid chromatography-electrospray-tandem mass spectrometry. Talanta $83,410-24$.

Loraine, G.A., Pettigrove, M.E., 2006. Seasonal variations in concentrations of pharmaceuticals and personal care products in drinking water and reclaimed wastewater in southern California. Environ. Sci. Technol. 40, 687-95.

Martins, N., Pereira, R., Abrantes, N., Pereira, J., Gonçalves, F., Marques, C.R., 2012. Ecotoxicological effects of ciprofloxacin on freshwater species: data integration and derivation of toxicity thresholds for risk assessment. Ecotoxicology 21, 1167-76.

Miège, C., Choubert, J.M., Ribeiro, L., Eusèbe, M., Coquery, M., 2009. Fate of pharmaceuticals and personal care products in wastewater treatment plants--conception of a database and first results. Environ. Pollut. 157, 1721-6. 
Mimeault, C., Trudeau, V.L., Moon, T.W., 2006. Waterborne gemfibrozil challenges the hepatic antioxidant defense system and down-regulates peroxisome proliferator-activated receptor beta (PPARbeta) mRNA levels in male goldfish (Carassius auratus). Toxicology $228,140-50$.

Mompelat, S., Le Bot, B., Thomas, O., 2009. Occurrence and fate of pharmaceutical products and by-products, from resource to drinking water. Environ. Int. 35, 803-14.

Nikolaou, A., Meric, S., Fatta, D., 2007. Occurrence patterns of pharmaceuticals in water and wastewater environments. Anal. Bioanal. Chem. 387, 1225-34.

Petrovic, M., Barceló, D., 2007. LC-MS for identifying photodegradation products of pharmaceuticals in the environment. TrAC Trends Anal. Chem. 26, 486-493.

Petrovic, M., Gros, M., Barcelo, D., 2006. Multi-residue analysis of pharmaceuticals in wastewater by ultra-performance liquid chromatography-quadrupole-time-of-flight mass spectrometry. J. Chromatogr. A 1124, 68-81.

Pomati, F., Netting, A.G., Calamari, D., Neilan, B. a, 2004. Effects of erythromycin, tetracycline and ibuprofen on the growth of Synechocystis sp. and Lemna minor. Aquat. Toxicol. 67, 387-96.

Pounds, N., Maclean, S., Webley, M., Pascoe, D., Hutchinson, T., 2008. Acute and chronic effects of ibuprofen in the mollusc Planorbis carinatus (Gastropoda: Planorbidae). Ecotoxicol. Environ. Saf. 70, 47-52.

Richards, S.M., Wilson, C.J., Johnson, D.J., Castle, D.M., Lam, M., Mabury, S. a, Sibley, P.K., Solomon, K.R., 2004. Effects of pharmaceutical mixtures in aquatic microcosms. Environ. Toxicol. Chem. 23, 1035-42.

Roberts, P.H., Thomas, K. V, 2006. The occurrence of selected pharmaceuticals in wastewater effluent and surface waters of the lower Tyne catchment. Sci. Total Environ. 356, 143-53.

Salgado, R., Marques, R., Noronha, J.P., Carvalho, G., Oehmen, a, Reis, M. a M., 2012. Assessing the removal of pharmaceuticals and personal care products in a full-scale activated sludge plant. Environ. Sci. Pollut. Res. Int. 19, 1818-27.

Salgado, R., Marques, R., Noronha, J.P., Mexia, J.T., Carvalho, G., Oehmen, a, Reis, M. a M., 2011. Assessing the diurnal variability of pharmaceutical and personal care products in a full-scale activated sludge plant. Environ. Pollut. 159, 2359-67.

Salgado, R., Noronha, J.P., Oehmen, a, Carvalho, G., Reis, M. a M., 2010. Analysis of 65 pharmaceuticals and personal care products in 5 wastewater treatment plants in Portugal using a simplified analytical methodology. Water Sci. Technol. 62, 2862-71.

Santos, L.H.M.L.M., Araújo, a N., Fachini, A., Pena, a, Delerue-Matos, C., Montenegro, M.C.B.S.M., 2010. Ecotoxicological aspects related to the presence of pharmaceuticals in the aquatic environment. J. Hazard. Mater. 175, 45-95. 
Santos, L.H.M.L.M., Gros, M., Rodriguez-Mozaz, S., Delerue-Matos, C., Pena, A., Barceló, D., Montenegro, M.C.B.S.M., 2013. Contribution of hospital effluents to the load of pharmaceuticals in urban wastewaters: identification of ecologically relevant pharmaceuticals. Sci. Total Environ. 461-462, 302-16.

Seifrtová, M., Pena, A., Lino, C.M., Solich, P., 2008. Determination of fluoroquinolone antibiotics in hospital and municipal wastewaters in Coimbra by liquid chromatography with a monolithic column and fluorescence detection. Anal. Bioanal. Chem. 391, 799805.

Sim, W.-J., Lee, J.-W., Lee, E.-S., Shin, S.-K., Hwang, S.-R., Oh, J.-E., 2011. Occurrence and distribution of pharmaceuticals in wastewater from households, livestock farms, hospitals and pharmaceutical manufactures. Chemosphere 82, 179-86.

Sousa, M.A., Gonçalves, C., Cunha, E., Hajšlová, J., Alpendurada, M.F., 2011. Cleanup strategies and advantages in the determination of several therapeutic classes of pharmaceuticals in wastewater samples by SPE-LC-MS/MS. Anal. Bioanal. Chem. 399, 807-22.

Sui, Q., Huang, J., Deng, S., Chen, W., Yu, G., 2011. Seasonal variation in the occurrence and removal of pharmaceuticals and personal care products in different biological wastewater treatment processes. Environ. Sci. Technol. 45, 3341-8.

Sun, Q., Lv, M., Hu, A., Yang, X., Yu, C.-P., 2013. Seasonal variation in the occurrence and removal of pharmaceuticals and personal care products in a wastewater treatment plant in Xiamen, China. J. Hazard. Mater.

Suominen, M., 2013. Simple and rapid method for monitoring pharmaceuticals in wastewater. Available at: https://dspace.cc.tut.fi/dpub/bitstream/handle/123456789/21571/Suominen.pdf?sequence $=1$. Accessed on 09.07.2014, 2013 .

Ternes, T., Bonerz, M., Schmidt, T., 2001. Determination of neutral pharmaceuticals in wastewater and rivers by liquid chromatography-electrospray tandem mass spectrometry. J. Chromatogr. A 938, 175-85.

Vazquez-Roig, P., Andreu, V., Blasco, C., Picó, Y., 2012. Risk assessment on the presence of pharmaceuticals in sediments, soils and waters of the Pego-Oliva Marshlands (Valencia, eastern Spain). Sci. Total Environ. 440, 24-32.

Vazquez-Roig, P., Andreu, V., Onghena, M., Blasco, C., Picó, Y., 2011. Assessment of the occurrence and distribution of pharmaceuticals in a Mediterranean wetland (L'Albufera, Valencia, Spain) by LC-MS/MS. Anal. Bioanal. Chem. 400, 1287-301.

Verlicchi, P., Al Aukidy, M., Jelic, a, Petrović, M., Barceló, D., 2014. Comparison of measured and predicted concentrations of selected pharmaceuticals in wastewater and surface water: a case study of a catchment area in the Po Valley (Italy). Sci. Total Environ. 470-471, 844-54. 
Verlicchi, P., Al Aukidy, M., Zambello, E., 2012. Occurrence of pharmaceutical compounds in urban wastewater: removal, mass load and environmental risk after a secondary treatment--a review. Sci. Total Environ. 429, 123-55.

Vieno, N., Sillanpää, M., 2014. Fate of diclofenac in municipal wastewater treatment plant A review. Environ. Int. 69C, 28-39.

Vieno, N.M., Tuhkanen, T., Kronberg, L., 2005. Seasonal variation in the occurrence of pharmaceuticals in effluents from a sewage treatment plant and in the recipient water. Environ. Sci. Technol. 39, 8220-6.

Watkinson, A.J., Murby, E.J., Kolpin, D.W., Costanzo, S.D., 2009. The occurrence of antibiotics in an urban watershed: from wastewater to drinking water. Sci. Total Environ. 407, 2711-23.

Weigel, S., Berger, U., Jensen, E., Kallenborn, R., Thoresen, H., Hühnerfuss, H., 2004. Determination of selected pharmaceuticals and caffeine in sewage and seawater from Tromsø/Norway with emphasis on ibuprofen and its metabolites. Chemosphere 56, 58392.

Wick, A., Fink, G., Joss, A., Siegrist, H., Ternes, T., 2009. Fate of beta blockers and psychoactive drugs in conventional wastewater treatment. Water Res. 43, 1060-74.

Xu, W., Zhang, G., Li, X., Zou, S., Li, P., Hu, Z., Li, J., 2007. Occurrence and elimination of antibiotics at four sewage treatment plants in the Pearl River Delta (PRD), South China. Water Res. 41, 4526-34.

Yang, L.H., Ying, G.G., Su, H.C., Stauber, J., Adams, M.S., Binet, M.T., 2008. Growthinhibiting effects of twelve antibacterial agents and their mixtures on the freshwater microalga. Environ. Toxicol. Chem. 27, 1201-1208.

Yuan, S., Jiang, X., Xia, X., Zhang, H., Zheng, S., 2012. Detection, occurrence and fate of 22 psychiatric pharmaceuticals in psychiatric hospital and municipal wastewater treatment plants in Beijing, China. Chemosphere 90, 2520-2525.

Yuan, S.-L., Li, X.-F., Jiang, X.-M., Zhang, H.-X., Zheng, S.-K., 2013. Simultaneous Determination of 13 Psychiatric Pharmaceuticals in Sewage by Automated Solid Phase Extraction and Liquid Chromatography-Mass Spectrometry. Chinese J. Anal. Chem. 41, 49-56.

Zenker, A., Cicero, M.R., Prestinaci, F., Bottoni, P., Carere, M., 2014. Bioaccumulation and biomagnification potential of pharmaceuticals with a focus to the aquatic environment. $\mathrm{J}$. Environ. Manage. 133, 378-87.

\section{FIGURE CAPTIONS}

Figure 1. Map of the study area indicating the sampling sites. 
Figure 2. Mass loads (mg/day/1000 inhab.) of the therapeutic groups in WWI (A) and WWE (B).

Figure 3. Geographic/seasonal variations on the occurrence of the selected pharmaceuticals in WWI (A) and WWE (B) (Anx - anxiolytics and hypnotics; Antib - antibiotics; Lip reg - Lipid regulators; Anti.inf - anti-inflammatories and analgesics).

Figure 4. Removal efficiencies of the different therapeutic groups (Anx - anxiolytics and hypnotics; Antib - antibiotics; Lip reg - Lipid regulators; Anti.inf - anti-inflammatories and analgesics). 


\section{TABLES}

Table 1. Therapeutics groups, characteristics, CAS number and national sales for the selected pharmaceuticals.

\begin{tabular}{llllll}
\hline \multicolumn{1}{c}{$\begin{array}{c}\text { Therapeutic } \\
\text { group }\end{array}$} & Pharmaceutical & Molecular formula & Molecular weight & \multicolumn{1}{c}{ CAS no. } & $\begin{array}{c}\text { National sales by } \\
\text { package }\end{array}$ \\
\hline $\begin{array}{l}\text { Anxiolytics and } \\
\text { hypnotics }\end{array}$ & Alprazolam & $\mathrm{C}_{17} \mathrm{H}_{13} \mathrm{ClN}_{4}$ & 308.8 & $28981-97-7$ & 2384299 \\
& Lorazepam & $\mathrm{C}_{15} \mathrm{H}_{10} \mathrm{~N}_{2} \mathrm{Cl}_{2} \mathrm{O}_{2}$ & 321.2 & $846-49-1$ & 1947305 \\
& Zolpidem & $\mathrm{C}_{19} \mathrm{H}_{21} \mathrm{~N}_{3} \mathrm{O}$ & 307.4 & $82626-48-0$ & 1089029 \\
Antibiotics & Azithromycin & $\mathrm{C}_{38} \mathrm{H}_{72} \mathrm{~N}_{2} \mathrm{O}_{12}$ & 749 & $83905-01-5$ & 944513 \\
& Ciprofloxacin & $\mathrm{C}_{17} \mathrm{H}_{18} \mathrm{FN}_{3} \mathrm{O}_{3}$ & 331.4 & $85721-33-1$ & 618465 \\
Lipid regulators & Bezafibrate & $\mathrm{C}_{19} \mathrm{H}_{20} \mathrm{ClNO}_{4}$ & 361.8 & $41859-67-0$ & 41450 \\
& Gemfibrozil & $\mathrm{C}_{15} \mathrm{H}_{22} \mathrm{O}_{3}$ & 250.3 & $25812-30-0$ & n.a. \\
& Simvastatin & $\mathrm{C}_{25} \mathrm{H}_{38} \mathrm{O}_{5}$ & 418.6 & $79902-63-9$ & 3440703 \\
Anti- & Diclofenac & $\mathrm{C}_{14} \mathrm{H}_{10} \mathrm{Cl}_{2} \mathrm{NNaO}_{2}$ & 318.1 & $15307-79-6$ & 1295809 \\
Inflammatories & Ibuprofen & $\mathrm{C}_{13} \mathrm{H}_{18} \mathrm{O}_{2}$ & 206.3 & $15687-27-1$ & 2063414 \\
and/or analgesics & Paracetamol & $\mathrm{C}_{8} \mathrm{H}_{9} \mathrm{NO}_{2}$ & 151.2 & $103-90-2$ & 3239035 \\
\hline
\end{tabular}

n.a. - Not available 
Table 2. Codes of the sampling points and characteristics of the wastewater treatment plants (WWTPs).

\begin{tabular}{|c|c|c|c|c|c|c|c|}
\hline WWTP Code & Region & $\begin{array}{l}\text { Population } \\
\text { equivalent }\end{array}$ & $\begin{array}{l}\text { Type of wastewater } \\
\text { treated }\end{array}$ & Discharging points & $\begin{array}{l}\text { Average loads } \\
(\mathrm{m} 3 / \mathbf{d})\end{array}$ & Type of treatment & Process \\
\hline WWTP 1 & North & 41955 & $\begin{array}{l}\text { Domestic. industrial } \\
\text { (residual) }\end{array}$ & Fervença River & 5685 & Secondary & $\begin{array}{l}\text { Activated Sludge with } \\
\text { conventional aeration }\end{array}$ \\
\hline WWTP 2 & North & 10000 & $\begin{array}{l}\text { Domestic. industrial } \\
\text { (mainly) }\end{array}$ & Tua River & 349 & Tertiary with UV & $\begin{array}{l}\text { Activated Sludge with } \\
\text { extended aeration }\end{array}$ \\
\hline WWTP 3 & North & 57748 & $\begin{array}{l}\text { Domestic. industrial } \\
\text { (residual) }\end{array}$ & Tâmega River & 8069 & Tertiary with UV & $\begin{array}{l}\text { Activated Sludge with } \\
\text { extended aeration }\end{array}$ \\
\hline WWTP 4 & North & 45257 & $\begin{array}{l}\text { Domestic. hospital and } \\
\text { industrial }\end{array}$ & Atlantic Ocean & 8580 & Tertiary with UV & $\begin{array}{l}\text { Activated Sludge with } \\
\text { medium load aeration }\end{array}$ \\
\hline WWTP 5 & North & 255557 & Domestic and industrial & Ave River & 15000 & Tertiary with UV & $\begin{array}{l}\text { Activated Sludge with } \\
\text { conventional and } \\
\text { extended aeration }\end{array}$ \\
\hline WWTP 6 & North & 300000 & Domestic & Atlantic Ocean & 66718 & Tertiary with UV & $\begin{array}{l}\text { Activated Sludge with } \\
\text { extended aeration }\end{array}$ \\
\hline WWTP 7 & Center & 213000 & Domestic and industrial & Mondego River & 36000 & Secondary & Trickling Filters \\
\hline WWTP 8 & Center & 6850 & $\begin{array}{l}\text { Domestic. hospital and } \\
\text { industrial }\end{array}$ & Mondego River & 600 & Secondary & Activated Sludge \\
\hline WWTP 9 & $\begin{array}{l}\text { Lisbon and } \\
\text { Tagus Valley }\end{array}$ & 700000 & Domestic and industrial & Trancão River & 60000 & $\begin{array}{l}\text { Secondary with } \\
\text { biofiltration }\end{array}$ & Activated Sludge \\
\hline WWTP 10 & $\begin{array}{l}\text { Lisbon and } \\
\text { Tagus Valley }\end{array}$ & 215000 & Domestic and industrial & Tagus River & 50000 & Tertiary with UV & Activated Sludge \\
\hline WWTP 11 & $\begin{array}{l}\text { Lisbon and } \\
\text { Tagus Valley }\end{array}$ & 756000 & Domestic & Tagus River & 140000 & Tertiary with UV & Biofiltration \\
\hline WWTP 12 & Alentejo & 60000 & $\begin{array}{l}\text { Domestic. hospital and } \\
\text { industrial }\end{array}$ & Xarrama River & 13720 & Tertiary with UV & $\begin{array}{l}\text { Activated Sludge with } \\
\text { medium load aeration }\end{array}$ \\
\hline WWTP 13 & Alentejo & 8700 & Domestic & Álamo Brook & 1239 & Tertiary with UV & $\begin{array}{l}\text { Activated Sludge with } \\
\text { extended aeration }\end{array}$ \\
\hline WWTP 14 & Algarve & 49547 & Domestic & Atlantic Ocean & 9239 & Tertiary with UV & $\begin{array}{l}\text { Activated Sludge with } \\
\text { extended aeration }\end{array}$ \\
\hline WWTP 15 & Algarve & 30766 & Domestic & Guadiana River & 6141 & Tertiary with UV & $\begin{array}{l}\text { Lagoons with extended } \\
\text { aeration }\end{array}$ \\
\hline
\end{tabular}


Table 3. WWI and WWE mass loads (mg/day/1000 inhab.), concentrations (ng $\mathrm{L}^{-1}$ ) and removal efficiencies (percentage) of the selected pharmaceuticals.

\begin{tabular}{|c|c|c|c|c|c|c|c|c|c|c|c|c|c|c|c|c|c|c|}
\hline \multirow[b]{3}{*}{$\begin{array}{l}\text { Therapeutic } \\
\text { group }\end{array}$} & \multicolumn{6}{|l|}{ WWI } & \multicolumn{6}{|l|}{ WWE } & \multicolumn{6}{|l|}{ Removal } \\
\hline & Spring & & Summer & & Total & & Spring & & Summer & & Total & & Spring & & Summer & & Total & \\
\hline & Range & Mean & Range & Mean & Range & Mean & Range & Mean & Range & Mean & Range & Mean & Range & Mean & Range & Mean & Range & Mean \\
\hline $\begin{array}{l}\text { Anxiolytics and } \\
\text { hypnotics }\end{array}$ & $\begin{array}{l}0.8-54.5 \\
(38.4-475.8)\end{array}$ & $\begin{array}{l}6.5 \\
(53.8)\end{array}$ & - & - & $\begin{array}{l}0.8-54.5 \\
(38.4-475.8)\end{array}$ & $\begin{array}{l}3.3 \\
(26.9)\end{array}$ & $\begin{array}{l}0.3-49.2 \\
(22.8-399.8)\end{array}$ & $\begin{array}{l}6.8 \\
(56.5)\end{array}$ & - & - & $\begin{array}{l}0.3-49.2 \\
(22.8-399.8)\end{array}$ & $\begin{array}{l}3.4 \\
(28.2)\end{array}$ & NE-70.0 & $\mathrm{NE}$ & - & - & NE-70.0 & $\mathrm{NE}$ \\
\hline Alprazolam & - & - & - & - & - & - & - & - & - & - & - & - & - & - & - & - & - & - \\
\hline Lorazepam & $\begin{array}{l}0.8-54.5 \\
(38.4-475.8)\end{array}$ & $\begin{array}{l}19.5 \\
(161.5)\end{array}$ & - & - & $\begin{array}{l}0.8-54.5 \\
(38.4-475.8)\end{array}$ & $\begin{array}{l}9.8 \\
(80.8)\end{array}$ & $\begin{array}{l}0.3-49.2 \\
(22.8-399.8)\end{array}$ & $\begin{array}{l}20.5 \\
(169.4)\end{array}$ & - & - & $\begin{array}{l}0.3-49.2 \\
(22.8-399.8)\end{array}$ & $\begin{array}{l}10.3 \\
(84.7)\end{array}$ & NE-70.0 & $\mathrm{NE}$ & - & - & NE-70.0 & $\mathrm{NE}$ \\
\hline Zolpidem & - & - & - & - & - & - & - & - & - & - & - & - & - & - & - & - & - & - \\
\hline Antibiotics & $\begin{array}{l}\text { n.d.-133.2 } \\
\text { (n.d.-719.3) }\end{array}$ & $\begin{array}{l}11.3 \\
(82.5)\end{array}$ & $\begin{array}{l}\text { n.d.-3627.4 } \\
\text { (n.d.-17500.0) }\end{array}$ & $\begin{array}{l}650.1 \\
(4333.4)\end{array}$ & $\begin{array}{l}\text { n.d.-3627.4 } \\
\text { (n.d.-17500.0) }\end{array}$ & $\begin{array}{l}330.7 \\
(2208.0)\end{array}$ & $\begin{array}{l}\text { n.d.-85.5 } \\
\text { (n.d.-608.6) }\end{array}$ & $\begin{array}{l}6.0 \\
(40.0)\end{array}$ & $\begin{array}{l}\text { n.d-836.5 } \\
\text { (n.d-9800.0) }\end{array}$ & $\begin{array}{l}131.3 \\
(1191.3)\end{array}$ & $\begin{array}{l}\text { n.d-836.5 } \\
\text { (n.d-9800.0) }\end{array}$ & $\begin{array}{l}68.6 \\
(615.7)\end{array}$ & NE-100.0 & 47.2 & NE-100.0 & 79.8 & NE-100.0 & 79.3 \\
\hline Azithromycin & $\begin{array}{l}\text { n.d.-133.2 } \\
\text { (n.d.-719.3) }\end{array}$ & $\begin{array}{l}14.4 \\
(84.5)\end{array}$ & - & - & $\begin{array}{l}\text { n.d.-133.2 } \\
\text { (n.d.-719.3) }\end{array}$ & $\begin{array}{l}7.2 \\
(42.3)\end{array}$ & - & - & $\begin{array}{l}\text { n.d.-11.7 } \\
\text { (n.d.-200.0) }\end{array}$ & $\begin{array}{l}0.8 \\
(13.3)\end{array}$ & $\begin{array}{l}\text { n.d.-11.7 } \\
\text { (n.d.-200.0) }\end{array}$ & $\begin{array}{l}0.4 \\
(6.7)\end{array}$ & 100.0 & 100.0 & $\mathrm{NE}$ & $\mathrm{NE}$ & NE-100.0 & 94.6 \\
\hline Ciprofloxacin & $\begin{array}{l}\text { n.d.-67.7 } \\
\text { (n-d- }-792.7)\end{array}$ & $\begin{array}{l}8.1 \\
(80.5)\end{array}$ & $\begin{array}{l}\text { n.d.-3627.4 } \\
\text { (n.d.-17500.0) }\end{array}$ & $\begin{array}{l}1300.2 \\
(8666.7)\end{array}$ & $\begin{array}{l}\text { n.d.-3627.4 } \\
\text { (n.d.-17500.0) }\end{array}$ & $\begin{array}{l}654.2 \\
(4373.6)\end{array}$ & $\begin{array}{l}\text { n.d.-85.5 } \\
\text { (n.d.-608.6) }\end{array}$ & $\begin{array}{l}11.9 \\
(80.0)\end{array}$ & $\begin{array}{l}\text { n.d-836.5 } \\
\text { (n.d-9800.0) }\end{array}$ & $\begin{array}{l}261.7 \\
(2369.3)\end{array}$ & $\begin{array}{l}\text { n.d-836.5 } \\
\text { (n.d-9800.0) }\end{array}$ & $\begin{array}{l}136.8 \\
(1224.7)\end{array}$ & NE-100.0 & $\mathrm{NE}$ & NE-100.0 & 79.9 & NE-100.0 & 79.1 \\
\hline Lipid regulators & $\begin{array}{l}0.7-38.5 \\
(49.4-187.9)\end{array}$ & $\begin{array}{l}9.9 \\
(77.9)\end{array}$ & $\begin{array}{l}\text { n.d.-2052.4 } \\
\text { (n.d.-8500.0) }\end{array}$ & $\begin{array}{l}358.2 \\
(2802.1)\end{array}$ & $\begin{array}{l}\text { n.d.-2052.4 } \\
\text { (n.d.-8500.0) }\end{array}$ & $\begin{array}{l}184.1 \\
(1440.0)\end{array}$ & $\begin{array}{l}\text { n.d.-26.7 } \\
\text { (n.d.-369.8) }\end{array}$ & $\begin{array}{l}6.0 \\
(63.6)\end{array}$ & $\begin{array}{l}\text { n.d.-240.0 } \\
\text { (n.d.-2400.0) }\end{array}$ & $\begin{array}{l}38.3 \\
(332.2)\end{array}$ & $\begin{array}{l}\text { n.d.-240.0 } \\
\text { (n.d.-2400.0) }\end{array}$ & $\begin{array}{l}22.3 \\
(192.9)\end{array}$ & NE-100.0 & 36.2 & NE-100.0 & 89.3 & NE-100.0 & 87.9 \\
\hline Bezafibrate & $\begin{array}{l}0.7-28.3 \\
(35.6-152.8)\end{array}$ & $\begin{array}{l}11.3 \\
(87.4)\end{array}$ & $\begin{array}{l}32.0-1348.8 \\
(420.0-6000.0)\end{array}$ & $\begin{array}{l}331.8 \\
(2651.3)\end{array}$ & $\begin{array}{l}0.7-1348.8 \\
(35.6-6000.0)\end{array}$ & $\begin{array}{l}171.6 \\
(1369.4)\end{array}$ & $\begin{array}{l}\text { n.d.-13.6 } \\
\text { (n.d.-73.3) }\end{array}$ & $\begin{array}{l}2.6 \\
(19.7)\end{array}$ & $\begin{array}{l}0.9-240.0 \\
(40.0-2400.0)\end{array}$ & $\begin{array}{l}68.9 \\
(584.7)\end{array}$ & $\begin{array}{l}\text { n.d.-240.0 } \\
\text { (n.d.-2400.0) }\end{array}$ & $\begin{array}{l}35.6 \\
(302.2)\end{array}$ & $24.1-100.0$ & 77.2 & $25.3-99.3$ & 79.2 & $24.1-100.0$ & 79.2 \\
\hline Gemfibrozil & $\begin{array}{l}0.7-38.5 \\
(49.4-187.9)\end{array}$ & $\begin{array}{l}10.6 \\
(85.4)\end{array}$ & $\begin{array}{l}\text { n.d.-1138.5 } \\
\text { (n.d.-4300.0) }\end{array}$ & $\begin{array}{l}103.2 \\
(511.7)\end{array}$ & $\begin{array}{l}\text { n.d.-1138.5 } \\
\text { (n.d.-4300.0) }\end{array}$ & $\begin{array}{l}56.9 \\
(298.6)\end{array}$ & $\begin{array}{l}0.6-14.9 \\
(29.2-133.9)\end{array}$ & $\begin{array}{l}7.3 \\
(62.5)\end{array}$ & $\begin{array}{l}\text { n.d.-169.0 } \\
\text { (n.d.-1500.0) }\end{array}$ & $\begin{array}{l}45.9 \\
(412.0)\end{array}$ & $\begin{array}{l}\text { n.d.-169.0 } \\
\text { (n.d.-1500.0) }\end{array}$ & $\begin{array}{l}26.6 \\
(237.3)\end{array}$ & NE-79.7 & 31.0 & NE-100.0 & 55.5 & NE-100.0 & 53.2 \\
\hline Simvastatin & $\begin{array}{l}0.8-15.7 \\
(45.7-76.5)\end{array}$ & $\begin{array}{l}7.8 \\
(60.8)\end{array}$ & $\begin{array}{l}\text { n.d.-2052.4 } \\
\text { (n.d.-8500.0) }\end{array}$ & $\begin{array}{l}639.6 \\
(5243.3)\end{array}$ & $\begin{array}{l}\text { n.d.-2052.4 } \\
\text { (n.d.-8500.0) }\end{array}$ & $\begin{array}{l}323.7 \\
(2652.1)\end{array}$ & $\begin{array}{l}0.7-26.7 \\
(26.3-369.8)\end{array}$ & $\begin{array}{l}9.1 \\
(78.6)\end{array}$ & - & - & $\begin{array}{l}0.7-26.7 \\
(26.3-369.8)\end{array}$ & $\begin{array}{l}4.6 \\
(39.3)\end{array}$ & NE-53.4 & $\mathrm{NE}$ & 100.0 & 100.0 & NE-100.0 & 98.6 \\
\hline $\begin{array}{l}\text { Anti- } \\
\text { inflammatories } \\
\text { and/or analgesics }\end{array}$ & $\begin{array}{l}\text { n.d.-7780.5 } \\
\text { (n.d.-48878.0) }\end{array}$ & $\begin{array}{l}1133.5 \\
(8744.8)\end{array}$ & $\begin{array}{l}\text { n.d.-16900.2 } \\
\text { (n.d.-66700.0) }\end{array}$ & $\begin{array}{l}1545.3 \\
(10929.4)\end{array}$ & $\begin{array}{l}\text { n.d.-16900.2 } \\
\text { (n.d.-66700.0) }\end{array}$ & $\begin{array}{l}1339.4 \\
(9837.2)\end{array}$ & $\begin{array}{l}\text { n.d.-139.8 } \\
\text { (n.d.-995.4) }\end{array}$ & $\begin{array}{l}10.0 \\
(78.8)\end{array}$ & $\begin{array}{l}\text { n.d.-177.4 } \\
\text { (n.d.-670.0) }\end{array}$ & $\begin{array}{l}20.0 \\
(164.3)\end{array}$ & $\begin{array}{l}\text { n.d.-177.4 } \\
\text { (n.d.-670.0) }\end{array}$ & $\begin{array}{l}15.0 \\
(121.6)\end{array}$ & NE-100.0 & 99.1 & NE-100.0 & 98.7 & NE-100.0 & 98.9 \\
\hline Diclofenac & $\begin{array}{l}\text { n.d.-43.1 } \\
\text { (n.d.-232.7) }\end{array}$ & $\begin{array}{l}8.7 \\
(67.4)\end{array}$ & $\begin{array}{l}\text { n.d.-635.5 } \\
\text { (n.d.-2400.0) }\end{array}$ & $\begin{array}{l}46.0 \\
(183.0)\end{array}$ & $\begin{array}{l}\text { n.d.-635.5 } \\
\text { (n.d.-2400.0) }\end{array}$ & $\begin{array}{l}27.4 \\
(125.2)\end{array}$ & $\begin{array}{l}\text { n.d.-16.4 } \\
\text { (n.d.-90.1) }\end{array}$ & $\begin{array}{l}3.1 \\
(24.9)\end{array}$ & $\begin{array}{l}\text { n.d.-177.4 } \\
\text { (n.d.-670.0) }\end{array}$ & $\begin{array}{l}26.7 \\
(154.8)\end{array}$ & $\begin{array}{l}\text { n.d.-177.4 } \\
\text { (n.d.-670.0) }\end{array}$ & $\begin{array}{l}14.9 \\
(89.9)\end{array}$ & NE-100.0 & 64.6 & NE-100.0 & 42.0 & NE-100.0 & 45.6 \\
\hline Ibuprofen & $\begin{array}{l}5.3-1100.7 \\
(305.2-6810.0)\end{array}$ & $\begin{array}{l}404.4 \\
(2982.3)\end{array}$ & $\begin{array}{l}\text { n.d.-1266.9 } \\
\text { (n.d.-8600.0) }\end{array}$ & $\begin{array}{l}505.2 \\
(3920.0)\end{array}$ & $\begin{array}{l}\text { n.d.-1266.9 } \\
\text { (n.d.-8600.0) }\end{array}$ & $\begin{array}{l}454.8 \\
(3451.2)\end{array}$ & $\begin{array}{l}\text { n.d.-139.8 } \\
\text { (n.d.-995.4) }\end{array}$ & $\begin{array}{l}20.7 \\
(157.8)\end{array}$ & $\begin{array}{l}\text { n.d.-116.9 } \\
\text { (n.d.-1370.0) }\end{array}$ & $\begin{array}{l}33.3 \\
(338.0)\end{array}$ & $\begin{array}{l}\text { n.d.-116.9 } \\
\text { (n.d.-1370.0) }\end{array}$ & $\begin{array}{l}27.0 \\
(247.9)\end{array}$ & $57.4-100.0$ & 94.9 & $61.4-100.0$ & 93.4 & $57.4-100.0$ & 94.1 \\
\hline Paracetamol & $\begin{array}{l}59.2-7780.5 \\
(1347.7-48878.0)\end{array}$ & $\begin{array}{l}2987.4 \\
(23184.8)\end{array}$ & $\begin{array}{l}217.8-16900.2 \\
(4200.0-66700.0)\end{array}$ & $\begin{array}{l}4084.6 \\
(28685.3)\end{array}$ & $\begin{array}{l}59.2-16900.2 \\
(1347-66700.0)\end{array}$ & $\begin{array}{l}3536.0 \\
(25935.1)\end{array}$ & $\begin{array}{l}\text { n.d.-80.4 } \\
\text { (n.d.-530.7) }\end{array}$ & $\begin{array}{l}6.1 \\
(53.7)\end{array}$ & - & - & $\begin{array}{l}\text { n.d.-80.4 } \\
\text { (n.d.-530.7) }\end{array}$ & $\begin{array}{l}3.1 \\
(26.9)\end{array}$ & $82.5-100.0$ & 99.8 & 100.0 & 100.0 & $82.5-100.0$ & 99.9 \\
\hline $\begin{array}{l}\text { All } \\
\text { pharmaceuticals }\end{array}$ & $\begin{array}{l}\text { n.d.-7780.5 } \\
\text { (n.d.-48878.0) }\end{array}$ & $\begin{array}{l}231.5 \\
(1786.3)\end{array}$ & $\begin{array}{l}\text { n.d.-16900.2 } \\
\text { (n.d.-66700.0) }\end{array}$ & $\begin{array}{l}467.4 \\
(3324.1)\end{array}$ & $\begin{array}{l}\text { n.d.-16900.2 } \\
\text { (n.d.-66700.0) }\end{array}$ & $\begin{array}{l}429.3 \\
(3505.1)\end{array}$ & $\begin{array}{l}\text { n.d.-139.8 } \\
\text { (n.d.-995.4) }\end{array}$ & $\begin{array}{l}5.4 \\
(43.1)\end{array}$ & $\begin{array}{l}\text { n.d-836.5 } \\
\text { (n.d-9800.0) }\end{array}$ & $\begin{array}{l}29.2 \\
(258.1)\end{array}$ & $\begin{array}{l}\text { n.d-836.5 } \\
\text { (n.d-9800.0) }\end{array}$ & $\begin{array}{l}23.6 \\
(205.4)\end{array}$ & NE-100.0 & 97.7 & NE-100.0 & 93.8 & NE-100.0 & 94.5 \\
\hline
\end{tabular}

n.d. - not detected

$\mathrm{NE}$ - not eliminated (compounds for which the concentrations found in WWE were higher than the concentrations found in WWI) 
Table 4. Maximum environmental concentrations (MECs) in WWE. PNECs and RQs for algae, daphnids and fish for the studied pharmaceuticals.

\begin{tabular}{|c|c|c|c|c|c|c|c|c|}
\hline $\begin{array}{l}\text { Therapeutic } \\
\text { group }\end{array}$ & Pharmaceutical & 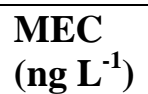 & PNEC $\left(\right.$ ng L $\left.^{-1}\right)$ algae & $\begin{array}{l}\text { RQ } \\
\text { algae }\end{array}$ & PNEC $\left(\right.$ ng $\left.L^{-1}\right)$ daphnids & $\begin{array}{l}\text { RQ } \\
\text { daphnids }\end{array}$ & PNEC $\left(\right.$ ng L $\left.^{-1}\right)$ fish & $\begin{array}{l}\text { RQ } \\
\text { fish }\end{array}$ \\
\hline $\begin{array}{l}\text { Anxiolytics and } \\
\text { hypnotics }\end{array}$ & Lorazepam & 399.8 & $1683^{\text {a.b }}$ & 0.238 & $44712^{\text {e.b }}$ & 0.009 & $49008^{\text {e.b }}$ & 0.008 \\
\hline \multirow[t]{2}{*}{ Antibiotics } & Azithromycin & 200.0 & $1874^{\text {a.b }}$ & 0.107 & $3023^{\text {e.b }}$ & 0.066 & $21945^{\text {e.b }}$ & 0.009 \\
\hline & Ciprofloxacin & 9800.0 & $1000^{\mathrm{c}, \mathrm{d}}$ (Ebert et al., 2011) & 9.800 & $180000^{\mathrm{c}, \mathrm{d}}$ (Martins et al., 2012) & 0.054 & $13131424^{\text {e.b }}$ & 0.001 \\
\hline \multirow[t]{3}{*}{ Lipid regulators } & Bezafibrate & 2400.0 & $1352^{a \cdot b}$ & 1.775 & $2300^{\mathrm{c}, \mathrm{d}}$ (Isidori et al., 2007) & 1.043 & $26435^{\text {e.b }}$ & 0.091 \\
\hline & Gemfibrozil & 1500.0 & $\begin{array}{l}312500^{c, d} \text { (Isidori et al., } \\
2007)\end{array}$ & 0.005 & $7800^{\mathrm{c}, \mathrm{d}}$ (Isidori et al., 2007) & 0.192 & $\begin{array}{l}150^{\mathrm{c}, \mathrm{d}} \text { (Mimeault, Trudeau, \& } \\
\text { Moon, 2006) }\end{array}$ & 10 \\
\hline & Simvastatin & 369.8 & $\begin{array}{l}22800^{\mathrm{b}} \text { (DeLorenzo \& } \\
\text { Fleming, 2008) }\end{array}$ & 0.016 & $\begin{array}{l}3.2^{\mathrm{f}} \text { (Dahl, Gorokhova, \& Breitholtz, } \\
2006)\end{array}$ & 115.563 & $765000^{\text {e. b }}$ & 0.000 \\
\hline \multirow{3}{*}{$\begin{array}{l}\text { Anti- } \\
\text { Inflammatories } \\
\text { and/or analgesics }\end{array}$} & Diclofenac & 670.0 & $\begin{array}{l}1000000^{\mathrm{c}, \mathrm{d}} \text { (Ferrari et al., } \\
2003 \text { ) }\end{array}$ & 0.001 & $20000^{\mathrm{c}, \mathrm{d}}$ (Haap et al., 2008) & 0.034 & $\begin{array}{l}50^{\mathrm{c}, \mathrm{d}} \text { (Hoeger, Köllner, } \\
\text { Dietrich, \& Hitzfeld, 2005) }\end{array}$ & 13.400 \\
\hline & Ibuprofen & 1370.0 & $\begin{array}{l}4010^{\mathrm{b}} \text { (Pomati, Netting, } \\
\text { Calamari, \& Neilan, 2004) }\end{array}$ & 0.342 & $102000^{\mathrm{c}, \mathrm{d}}$ (Pounds et al., 2008) & 0.013 & $41561^{\text {e.b }}$ & 0.033 \\
\hline & Paracetamol & 530.7 & $\begin{array}{l}134000^{\mathrm{b}} \text { (Henschel et al., } \\
\text { 1997) }\end{array}$ & 0.004 & $2040^{\mathrm{b}}$ (Dave and Herger 2012) & 0.260 & $\begin{array}{l}378000^{b} \text { (Henschel et al., } \\
\text { 1997) }\end{array}$ & 0.001 \\
\hline
\end{tabular}

${ }^{\mathrm{a}} \mathrm{EC} 50$ was estimated with ECOSAR

${ }^{\mathrm{b}} \mathrm{UF}=1000$

${ }^{\mathrm{c}}$ long-term data

${ }^{\mathrm{d}} \mathrm{UF}=10$

LC50 was estimated with ECOSAR

${ }^{\mathrm{f}} \mathrm{UF}=50$ (uncertainty factor used for LOEC in acute toxicity) 
FIGURES

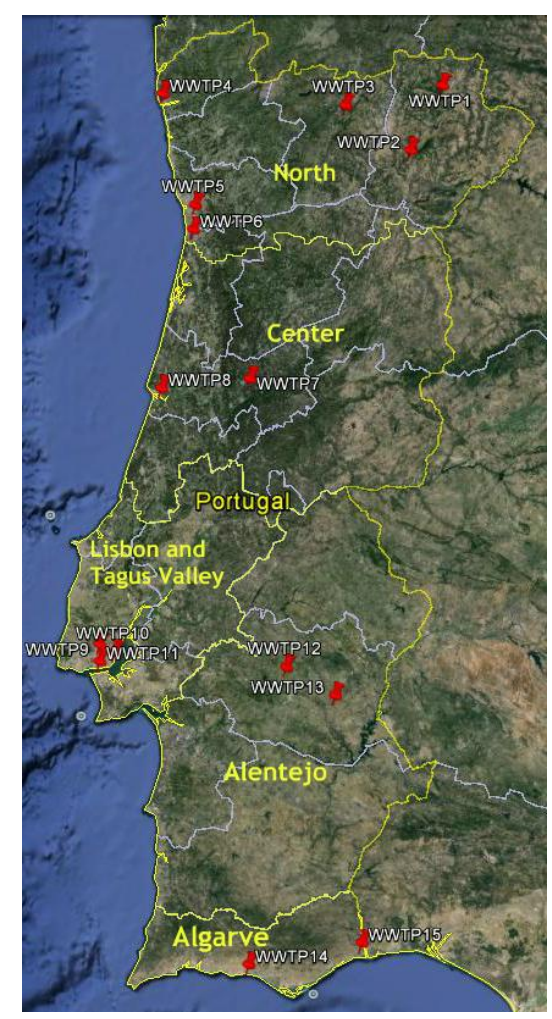

Figure 1 
(A)

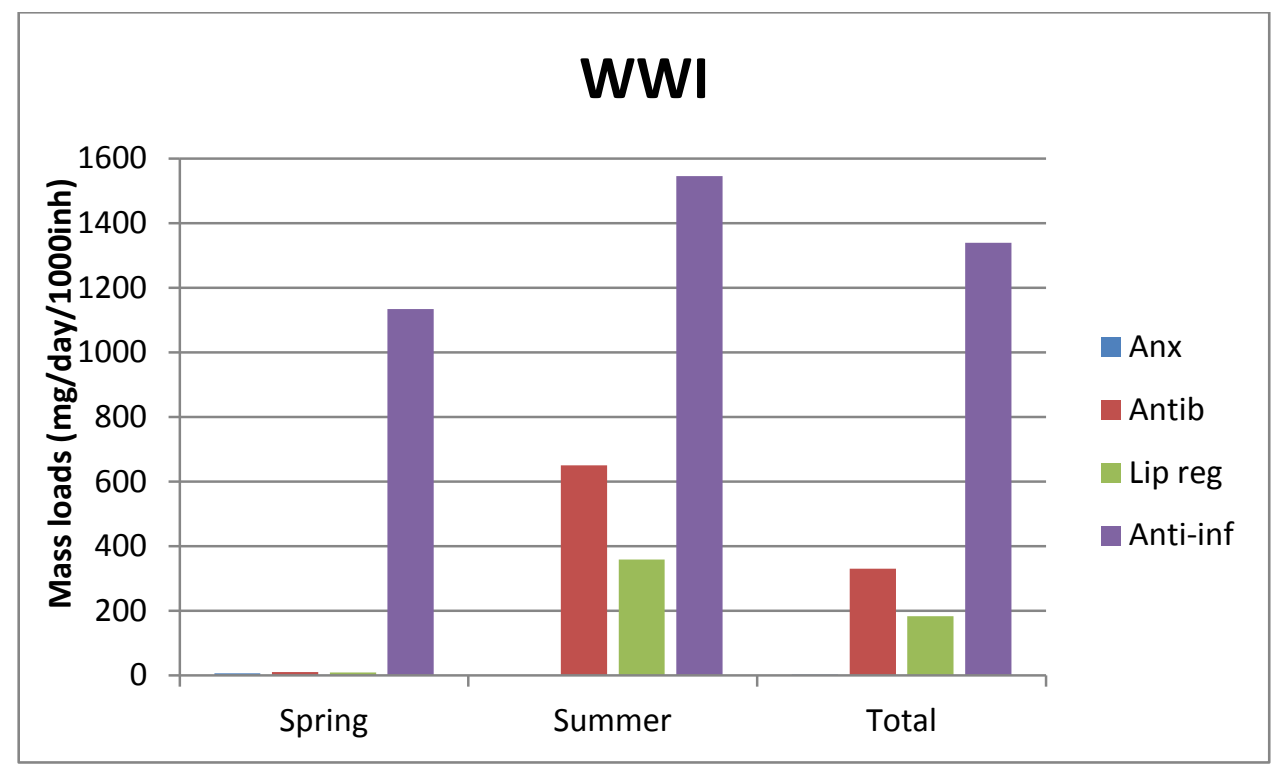

(B)

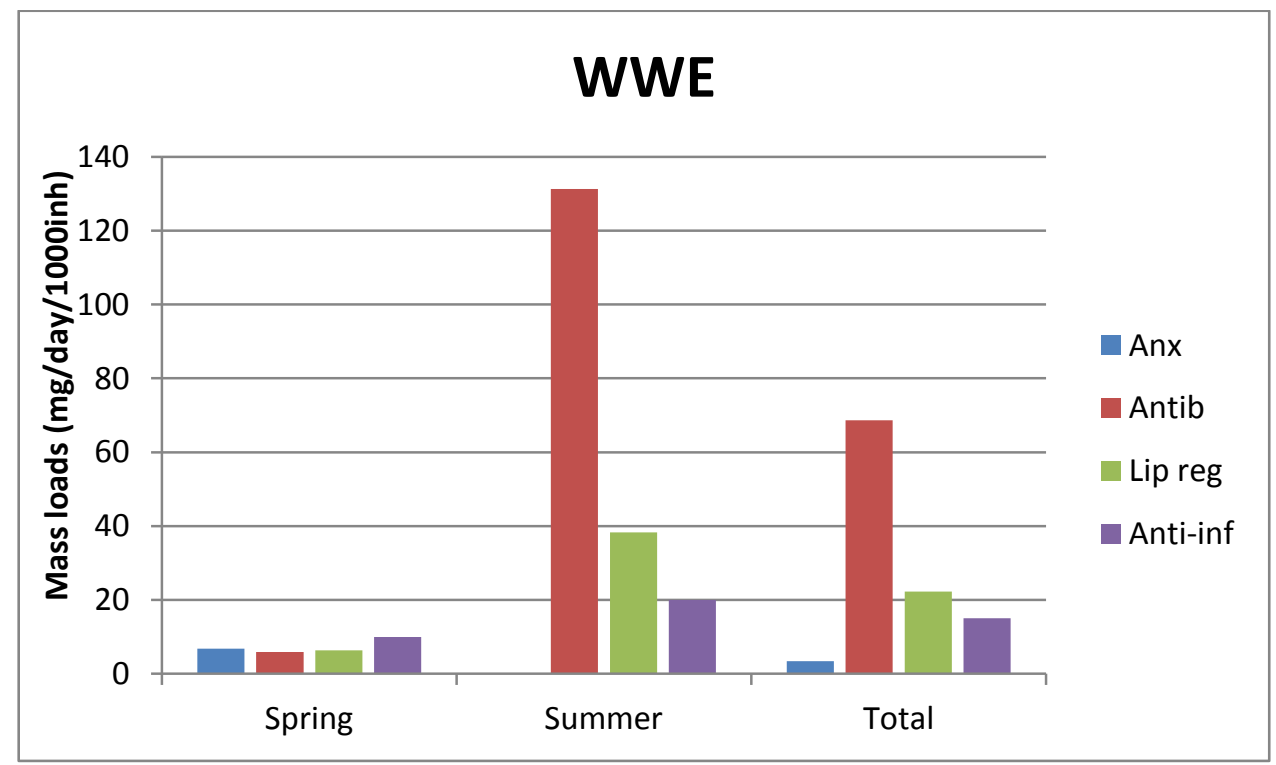

Figure 2 


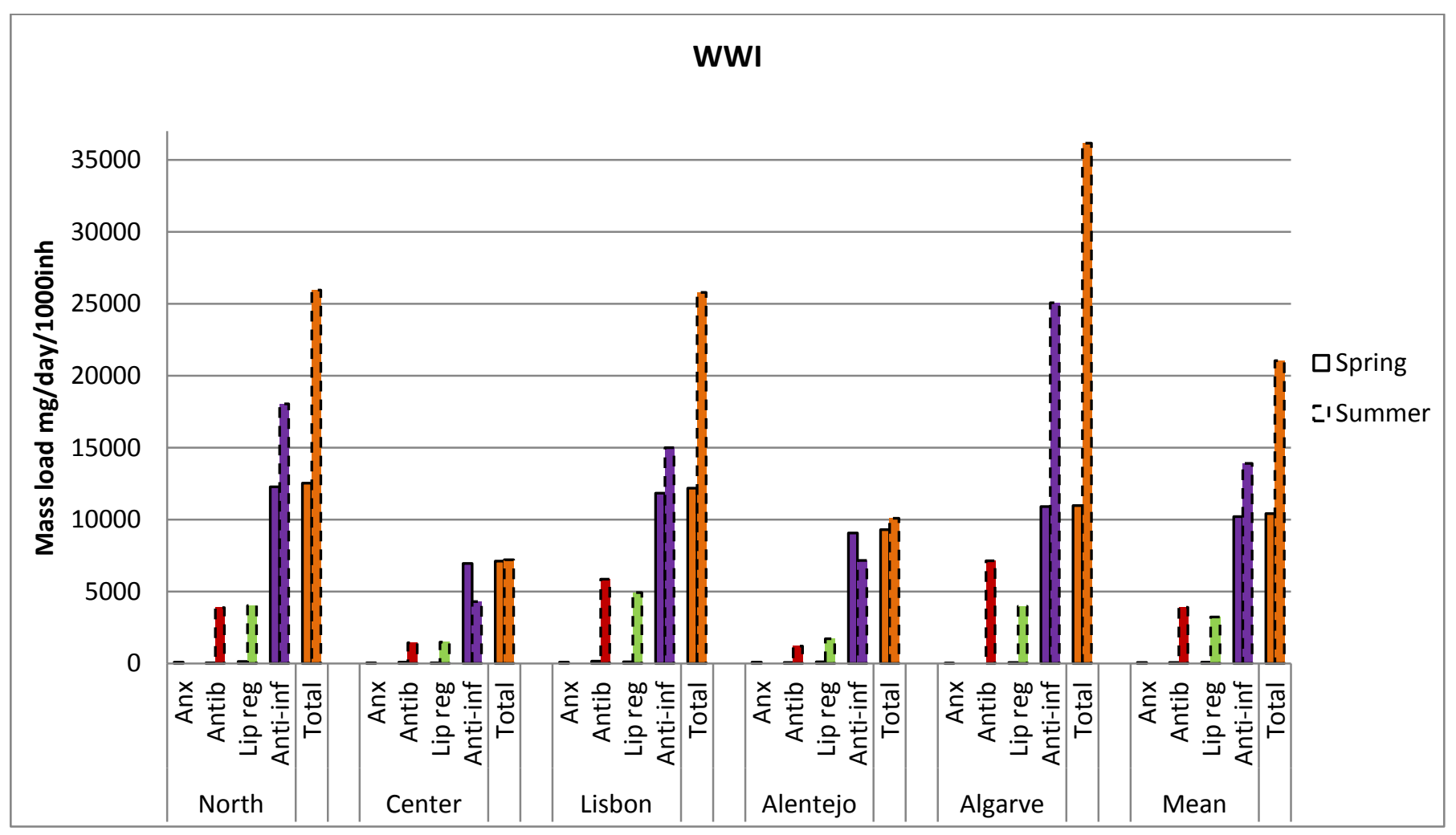

(B)

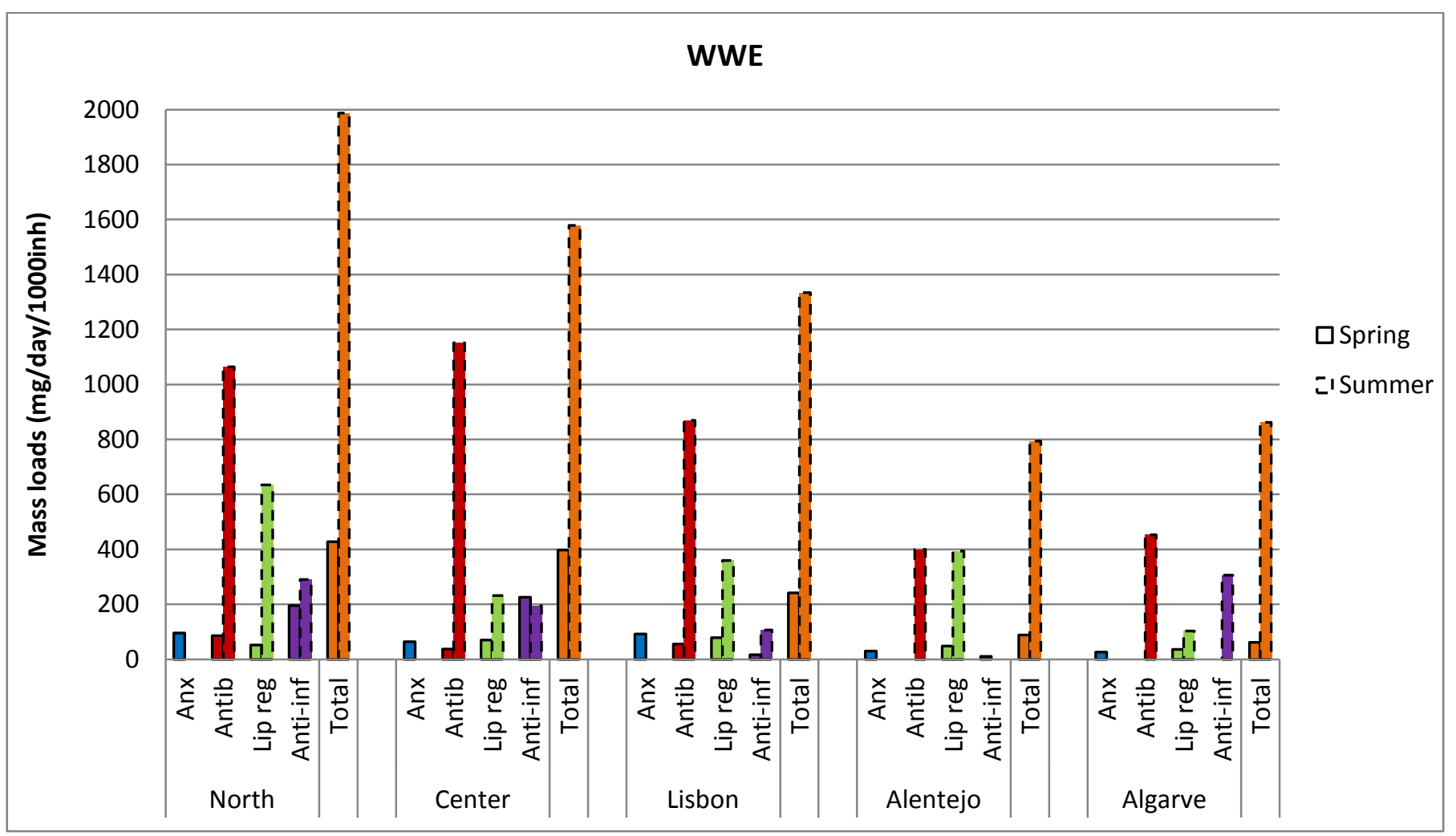

Figure 3 


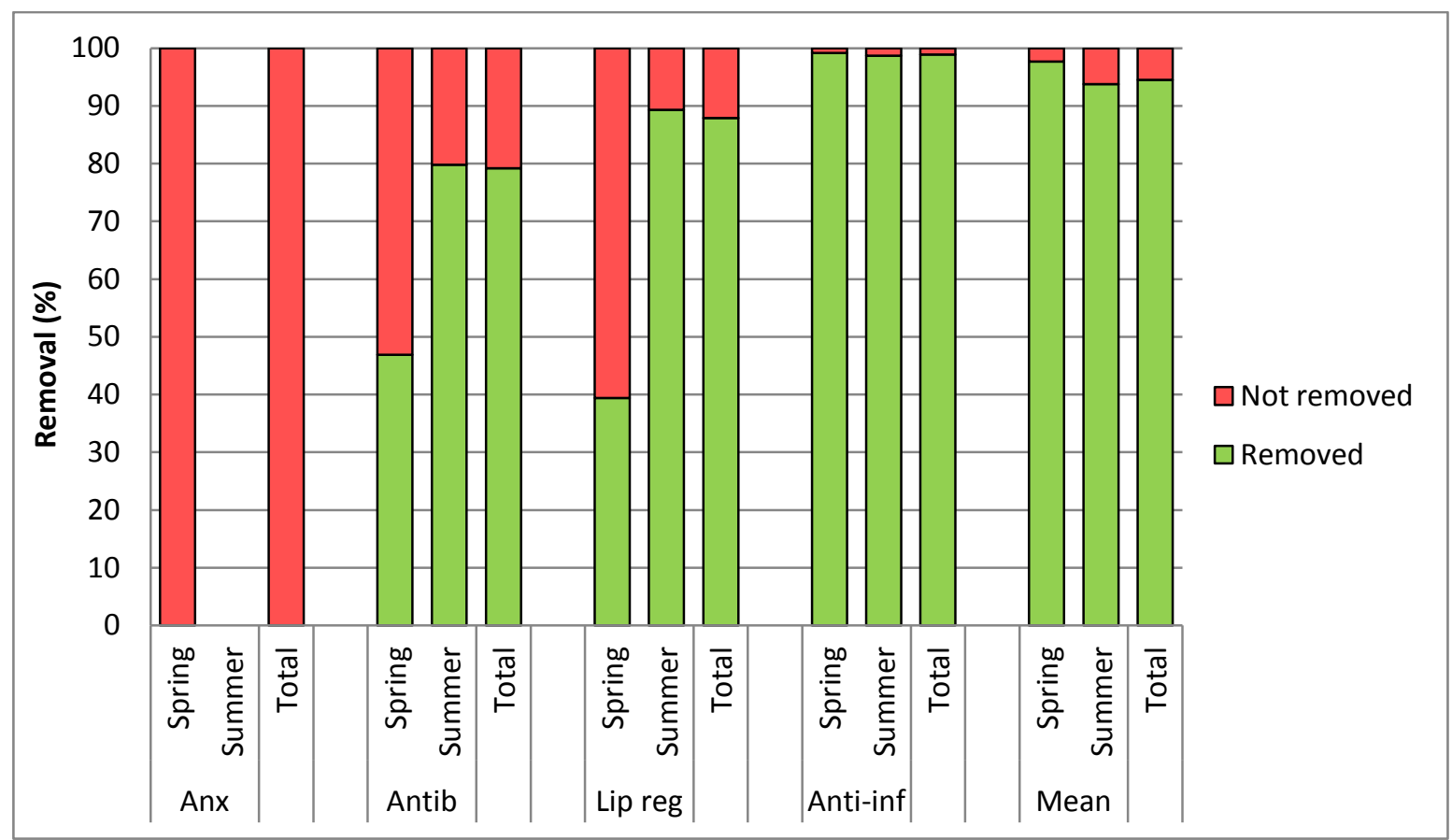

Figure 4 